Bryn Mawr College

Scholarship, Research, and Creative Work at Bryn Mawr College

Graduate School of Social Work and Social

Graduate School of Social Work and Social

Research Faculty Research and Scholarship

Research

2000

\title{
Maintaining Orthodoxy: The Depression-Era Struggle over Morphine Maintenance in California
}

Jim Baumohl

Bryn Mawr College, jbaumohl@brynmawr.edu

Let us know how access to this document benefits you.

Follow this and additional works at: http://repository.brynmawr.edu/gsswsr_pubs

Part of the Social Work Commons

\section{Custom Citation}

Baumohl, Jim. "Maintaining Orthodoxy: The Depression-Era Struggle over Morphine Maintenance in California." Contemporary Drug Problems 27, no. 1 (2000): 17-75.

This paper is posted at Scholarship, Research, and Creative Work at Bryn Mawr College. http://repository.brynmawr.edu/gsswsr_pubs/43

For more information, please contact repository@brynmawr.edu. 
Maintaining orthodoxy: The depression-era struggle over morphine maintenance in California

Baumohl, Jim

Contemporary Drug Problems; Spring 2000; 27, 1; ProQuest pg. 17

\title{
Maintaining orthodoxy: the Depression-era struggle over morphine maintenance in California
}

\author{
BY JIM BAUMOHL
}

With the closure of the Shreveport Clinic in 1923, the United States entered a 40-year period during which legal opiate maintenance was limited to a small number of registered medical addicts, most of them cancer patients. Addicts were demonized, hounded by law enforcement personnel, and rarely treated outside of jails.

Abstinence was the only legitimate goal of treatment. Quite correctly, historians regard the period between the mid-1920s and the mid-1960s as the Dark Ages of American drug policy. Even so, there was resistance to such therapeutic orthodoxy, notably on the West Coast. Indeed, the Los Angeles County Medical Association sponsored a morphine maintenance clinic during the early 1930s,

AUTHOR'S NOTE: For the time being, my many important debts must be acknowledged cryptically. The following people gave me editorial help and research assistance of one sort or another: Caroline Acker, Raymond Albert, Greg Bradsher, Chuck Burke, Diane Castle, David Courtwright, John Galliher, Kim Hopper, Pat Keats, Harry Levine, David Lewis, Shirley Lewis, Julia Littell, John McWilliams, Jennifer Nelson, David Pfeiffer, Judy Regueiro, Craig Reinarman, Richard Rogers, Fred Romanski, Sandy Schram, Ursula Sherman, Marianne Smith, Bill White, and Dea Zugby. Bryn Mawr College and the Lindesmith Center of the Open Society Institute generously defrayed the expenses. The opinions are mine.

(C) 2000 by Federal Legal Publications, Inc. 
only to see its doctors arrested and the clinic closed by federal authorities in spite of protests by the mayor of Los Angeles and the City of Los Angeles' director of public health. Relying on new primary sources, this paper chronicles the struggle between California maintenance advocates and the Federal Bureau of Narcotics during the Great Depression.

KEY PHRASES: American White Cross Association on Drug Addictions, California State Narcotic Hospital at Spadra, Federal Bureau of Narcotics, Los Angeles County Medical Association, opiate maintenance.

Behold now a ghost-the vagrant spectre of a dead mistake: Narcotic Clinics. Innocent in origin but vicious in effect, the mistake died young. But the evil spirit it awoke now and again roams the land, even to this day finding advocates to renew its mischief.

Harry J. Anslinger, ca. 1941

A clinic may not be a panacea, but even its most bitter enemies can offer nothing better.

Dr. George Parrish, $1935^{1}$

At the close of the 19th century, American legislators began to make into law their aversion to freely available opiates. Strict control accorded with temperance objectives, seemed likely to prevent a great deal of addiction and accidental poisoning, and appealed to the aspirations of doctors and druggists for greater income and respectability: Licensed dispensing might help regulate ruinous competition; restricted prescribing might give doctors some moral distance from the blighting addict trade and close the infamous all-night drug stores of the country's vice districts. As the Pacific Pharmacist opined, the sooner each druggist declined "to make money by trading upon the ignorance, the weaknesses or the vices of his customers, the sooner will pharmacy be looked up to as an art or a profession." Alas, there were some practi- 
tioners "who must be whipped into line by the sharp lash of the law."

In 1903 the American Pharmaceutical Association (APhA) adopted a model state law that based the availability of opiates on prescriptions filled by certified pharmacists and written by licensed medical practitioners (including dentists and veterinarians). It banned prescriptions for habitual users except "for the treatment of such habit." The APhA did not explicitly forbid the indefinite furnishing of maintenance doses to keep addicts out of withdrawal ("to satisfy their craving," in the language of the time). However, in 1909 the California State Board of Pharmacy specified the lawful, "good faith" use of opiates in treating addiction to be gradual withdrawal over several weeks. The California standard subsequently shaped enforcement of the epochal Harrison Narcotic Act, a federal statute effective March 1, 1915. ${ }^{3}$

Written as a revenue measure that enabled physicians and pharmacists to register as licensed handlers and dispensers of certain drugs, the Harrison Act avoided the appearance of regulating the practice of medicine, a responsibility guarded by the states. However, the Treasury Department, which administered Harrison, issued regulations in early 1915 that declared prescriptions valid only when written for "normal" doses. Addicts, including patients with advanced tuberculosis or severe chronic pain, now would be dependent on registered physicians, who were prohibited from prescribing the high doses necessary to exceed the tolerance levels of habitual users. As David Musto argued, from the implementation of Harrison, Treasury officials used it as the basis for an assault on maintenance. This reflected a growing consensus among physicians that "ambulatory treatment"-as either gradual reduction or maintenance-was always inferior to the asylum model of lengthy custody and enforced abstinence that had dominated the treatment of alcoholism since the $1880 \mathrm{~s}^{4}$ 
Still, the first years of Harrison Act enforcement were marked by conflict between Treasury's Narcotic Division and thousands of physicians who were principled, unwitting-and occasionally unscrupulous-violators of Harrison's alleged anti-maintenance warrant. Indeed, during the first years of the Harrison era, when doctors chose to fight rather than conform, local and district courts tended to hold that physicians acting in good faith could treat addiction as they saw fit, or that Harrison, as a mere revenue measure, could not infringe on a state's right to regulate medicine. At first, maintenance proved difficult to eliminate. But on the same day in March 1919 , the Treasury Department got two critically important, if razor-thin (5-4), rulings from the Supreme Court. U.S. $v$. Doremus (249 U.S. 86) affirmed the constitutionality of Harrison's requirement of valid prescriptions. Webb et al. v. U.S. (249 U.S. 96) put maintenance beyond the pale. Writing for the majority in Webb, Justice Day cast aside the subtleties of good faith and clinical necessity. Doubtless irritated with Dr. Webb, who prescribed huge quantities of morphine that likely were resold, Day wrote bluntly: "[T]o call such an order . . . a physician's prescription would be so plain a perversion of meaning that no discussion of the subject is required." Webb drove an effective (if fragile) wedge between addicts and legal sources of supply, and the decision's potential scope immediately alarmed local officials, for a real end to maintenance seemed to promise widespread suffering, crime, inundation of jails, and an overwhelming demand for hospital care. Treasury came under considerable pressure to help locals cope with the situation. ${ }^{5}$

Within two weeks of Webb, Treasury formally defined exceptions to anti-maintenance policy: Essentially, the elderly or incurably ill could be maintained if doctors affirmed that the drug was "necessary to sustain life." Such exceptions were already tolerated, and some states had rules and procedures for these cases. Since 1909 California's Board of Pharmacy had required physicians to register "medical" addicts. A 
Pennsylvania law of 1917 also required registration. This limited form of morphine maintenance became a little-known facet of therapeutic orthodoxy throughout the Harrison era, and although not without major ambiguities and attendant problems for doctors and patients, the practice was not insignificant: Between November 1918 and the end of September 1932, more than 17,000 addicts were registered in Pennsylvania, the registry adding about 1,000 persons per year even at the end of this period, almost two-thirds of whom suffered with cancer. ${ }^{6}$

At the end of July 1919, Treasury supported local initiatives to organize outpatient dispensaries-narcotic clinics-in response to $W e b b$. Whether clinics were ardently encouraged or merely permitted depended on the views and organizing zeal of any given regional collector of internal revenue, but whatever its quality, this support was expedient. As the commissioner of internal revenue saw it, in the wake of Webb "a system of relief" was required "whereby these unfortunate persons may be prevented from becoming menaces to the community and be ultimately salvaged." In the absence of available hospital treatment, clinics might examine addicts and give them "the minimum dose required to prevent their physical and nervous collapse." But the clinics were intended only as therapeutic staging areas. As the surgeon general advised the commissioner: "They serve to relieve the present crisis and later will serve as feeders to the institutions where real cure can be carried out."

As local and state officials were desperate for revenue in the midst of post-war recession and inflation, Treasury looked to the United States Public Health Service (PHS) to provide institutional care. The PHS had earlier resisted this idea; however, after Webb, and impressed by the fiscal and administrative architecture of the venereal disease clinics established during the war, the surgeon general found merit in a similar federal, state, and local partnership to manage addicts. The PHS would assume a coordinating role and, of vital impor- 
tance, take responsibility for addicts without legal residence anywhere. The France Bill, introduced in Congress in midAugust 1919, reflected this plan. France intended to create a federal matching grant program allowing states to establish Treasury-approved treatment systems drawing on PHS and military hospitals. Opposed as a harbinger of state medicine by substantial conservative elements in the American Medical Association (AMA) and spurned by a budget-slashing Senate, France failed on October 10th. ${ }^{8}$

Despite the defeat of the France Bill, more than 40 local clinics operated in the United States for some period between 1919 and 1923, They had in common the low-cost sale of morphine (and sometimes heroin and cocaine), but they were otherwise a mixed lot. Whatever their individual approaches and merits, however, all soon operated without the blessing of Treasury, which backtracked on clinics once it was clear that the France Bill was dead. Fortified by an April 1920 AMA resolution condemning ambulatory treatment, the Narcotic Division effectively discredited the clinics, closing most without resistance. As the rest of the story is usually told, after February 10, 1923, when the last, stubborn clinic closed in Shreveport, Louisiana, the United States entered a fourdecade period when no lawful opiate maintenance was available anywhere. From the closure of Shreveport to the establishment of methadone maintenance in New York City in 1965, American drug policy was, in the words of David Courtwright and his colleagues, "simple, consistent, and rigid." Addicts were demonized, hounded, subjected to draconian criminal penalties, and never treated except in the confines of hospital or jail. For the most part, only the patients of private sanitaria were spared immediate withdrawal. Abstinence was the only legitimate goal of treatment." Allowing for the oft-forgotten maintenance of the elderly or incurably ill and a "gray market" of private maintenance for the wellto-do, this story seems accurate. 
But notably absent is more than passing attention to how therapeutic orthodoxy was maintained, particularly in the face of continuing divergence and dissent. It was not reproduced effortlessly. In September 1930, when Harry J. Anslinger (1892-1975) began his 32-year reign as chief of the new Federal Bureau of Narcotics (FBN), he assumed command of a corps of agents recently infamous for feeding on street addicts while neglecting large dealers and for "black-jacking" doctors and druggists "into line." Anslinger promised a new dispensation, especially for "the professional classes" hounded by "field men" looking "to build up a good record" at their expense. ${ }^{10} \mathrm{He}$ could hardly have done otherwise. Rash enforcement, in part, caused Treasury important legal and political setbacks during the mid-1920s. In 1926 Congress rejected all six amendments to Harrison proposed by the department to "clear up certain points which have been raised in certain courts to the disadvantage of the government." One of these, which would have outlawed ambulatory treatment, intended to nullify a unanimous 1925 Supreme Court ruling (Linder v. U.S., 268 U.S. 5) that severely threatened Webb. Linder, involving a well-known Spokane (Washington) doctor who in 1922 prescribed small amounts of cocaine and morphine to an addict "stool pigeon," resuscitated the defense of professional good faith and reminded federal enforcers that Harrison could not trespass on a state's right to regulate medical practice. While the Court reaffirmed Harrison's constitutionality in 1928, it, like Congress, did nothing to blunt Linder's specific threat. That would require vigilant political work by the FBN."

One site of heresy was California, where maintenance advocates were concerned with a variety of related problems: the criminalization of addicts who were otherwise respectable citizens; the property crime (particularly car theft and burglary) attributed to addicts raising money for morphine (then the opiate of choice on the Coast); the dreary parade of addicts in and out of city and county lockups to no seeming end; the 
failure of a few months of state hospital care to do more than detoxify, treat abscesses, and promote weight gain; the prohibitive cost of massive long-term confinement; and the corruption of local, state, and federal police by drug money. After weighing such matters, Berkeley criminologist and former police chief August Vollmer (1876-1955) concluded in 1936 that "the first step in any plan to alleviate this dreadful affliction should be the establishment of federal control and dispensation-at cost-of habit-forming drugs." Vollmer's was a minority voice, but he was eminent and by no means alone. $^{12}$

\section{Maintaining orthodoxy}

I can't save enough to take a cure because it takes just a day's wages to keep down the craving. What I used to get in a drug store for twenty[-]five cents [five grains] costs just exactly five dollars now to peddlers. If I have it I can work with the rest of the huskies. But if I just get up in the morning and go to work without it I would not be able to walk in about six or eight hours. I therefore would lose my job. . . . If I had a place where I could go and buy my ration . . then I know I could taper off in a few weeks till I'd be nearly or all through with it. (G.A. Horner, Sacramento, August 9, 1919)

I have seen myself in the dark cold of the night, board the blinds . . . of a fast express train, in the mountains of northern California, and ride long and hard . . . to get a shot of morphine. I have kicked habits, cold turkey, in the box car jungles, and in many a cold and dreary jail house cell. . . . [W] hen a victim goes through all this misery, and continues to wade in said misery, it must thereby have an awful holt [sic] upon [him]. . . . [G]ive these who can prove incurable, a permit to use said medicine. (Anthony Votta, Rikers Island, New York, May 18, 1939'13)

The Jost Bill By January 1931, when William P. Jost, an obscure Alameda County Republican, introduced a maintenance bill in the California Assembly, the State Board of Pharmacy and its political allies had spent 20 years trying to create an effective alternative to incarceration on the one hand or maintenance 
on the other. A 1911 state commitment law sponsored by San Francisco's sheriff (who was also a powerful state senator) resulted in the wholesale transfer of addicts from county jails to state hospitals, but this merely enraged the asylum keepers, who by 1916 had regained substantial control of the commitment process. Successful bills to create a state hospital for addicts and alcoholics were pocketed by governors in 1913 and 1917 on grounds of economy. ${ }^{14}$ Thus, following Webb and the demise of the France Bill, and with the active collaboration of regional Treasury officials, the City of Los Angeles established a narcotic dispensary in February 1920.

This clinic treated 564 people during its short life. Over three-quarters of its registrants had been addicted for longer than five years, almost exclusively to morphine, and most were between 20 and 40 years old. Over $90 \%$ were white and native born. Almost all were unskilled and semiskilled workers in no position to pay one dollar per grain for morphine, the going price on the street. The clinic sold only morphine, for 10 cents per grain, and attempted to "balance" an addict on six to eight grains per day. Doses were reduced and withdrawal recommended consistent with the addict's health. Above all, the clinic attempted to support employment, as it was "infinitely better to have [addicts] at work using a moderate amount of morphine than turned loose on the streets desperate." Almost $20 \%$ of the registrants applied for hospitalization, which the clinic doctors considered "necessary for the last stage of treatment." The city health department paid for the private care of a few of these, and a few more were treated at the county hospital, but for most the clinic was "simply tiding [them] over an emergency." 15

Savagely disparaged by William Randolph Hearst's Los Angeles Examiner and quickly disowned by the Treasury Department, the clinic was closed by federal order in August 1920. Even so, the experiment persuaded some of the wisdom of the clinic model and even organized maintenance per se. The Los Angeles Times vigorously defended the "Hearst-assailed" 
clinic. The Board of Pharmacy, originally opposed to the Los Angeles clinic and to a much smaller one in San Diego, ultimately supported them. Frank Hutton, the attorney in charge of board prosecutions, wrote to the commissioner of internal revenue: "It is incomprehensible that a fair and impartial investigation of the Clinic idea would stamp it a failure." In Hutton's view, clinics accomplished "more good . . . in one day than all the prosecutions in one month." Neither Dr. L.M. Powers, the Los Angeles health commissioner, nor John P. Carter, Treasury's collector of internal revenue for Southern California, could understand opposition to the clinics; Carter was flummoxed by his agency's change of course. The committee of physicians and laymen advising the Los Angeles clinic was appalled by the "hidden ... and lying influence" marshaled against it. ${ }^{16}$

Carter's bafflement testified to his distance from policymaking. From its first enforcement of Harrison, Treasury's strategy was to subordinate treatment methods to drug control, and clinics, no less than private physicians, seemed likely sources of supply to the black market. Treasury also worried that clinics could undermine $W e b b$ by raising the question of why government was permitted to engage in a medical activity forbidden to private doctors. As regional supervisor Harry Smith explained to the press when closing the California clinics: "[A]mbulatory treatment is not legal, whether [by] a municipality or an individual."

In October 1923, some members of the defunct clinic's advisory committee, Powers and Carter among them, formed the nucleus of the Los Angeles-based Bureau of Drug Addiction. This was an ambitious organization with an unmistakably critical cast. Its medical division intended to establish "a properly equipped hospital unit" to treat addicts "within the limits of existing law," but its other divisions, one chaired by Vollmer, another by former Treasury Secretary William Gibbs McAdoo, aimed to produce reports with "particular emphasis" on cases where the medical division's work was 
hamstrung by existing law. ${ }^{18}$ The Bureau of Drug Addiction was also short-lived, but with the encouragement of the Board of Pharmacy, the mission of its medical division was assumed in late 1924 or early 1925 by the Narcotic Committee of the Los Angeles County Medical Association (LACMA).${ }^{19}$ For a number of years, one or more of the committee's doctors seem to have discreetly provided examinations and morphine prescriptions out of their own offices. By 1931, however, the committee was openly maintaining several dozen sick or elderly addicts at a clinic in the psychopathic ward of Los Angeles County General Hospital, and the clinic's director was paid 60 dollars per month by the city health department. ${ }^{20}$

Writing in 1937, Dr. Henry Smith Williams (1863-1943) observed that in the early 1930s the LACMA clinic "was an institution of rapidly growing fame. . . The work was known to the White Cross Societies, and projects were pending to petition legislatures to sanction the similar treatment of ambulatory addicts whose sole malady was drug addiction disease." Williams was referring most immediately to the Seattle-based White Cross Association on Drug Addictions, a group that advocated expanded treatment options for addicts, including maintenance. He also had in mind William Jost's White Cross-inspired Assembly Bill 1433. This would have allowed city and county health officers to prescribe up to four grains of morphine per day to "addicts of long standing . . . classed as incurables." 21

The LACMA Narcotic Committee's clinic was one referent for the Jost Bill; the California State Narcotic Hospital at Spadra was the other. Spadra was the work of Republican state senator Sanborn Young, of Santa Clara County, who in 1927 authored and steered a successful bill to create it after hospital bills failed in the legislature in 1921 and 1925. Located about 30 miles southeast of Los Angeles, Spadra opened in August 1928, superintended by Thomas F. Joyce, formerly the resident physician at New York City's Riverside 
Hospital and an experienced manager of addicts. Spadra was a modest attempt to provide institutional treatment (eight months to two years in duration) outside of county jails and existing state hospitals. ${ }^{22}$

Predictably, Spadra failed to escape the powerful gravity of California's decades-old struggle among state hospitals, jails, and commitment courts. From the Gold Rush on, state hospital superintendents, superior court judges, and county jailers had wrestled over the definition of appropriate candidates for hospital care. Hospital administrators always wanted promising therapeutic material; jailers always wanted to be rid of unruly drunkards and, by the 1880 s, addicts and the drug trade that followed them inside the lockups. For their part, committing magistrates responded to earnest pleas for lenience or medical treatment from the sometimes visibly ill people before them (or from their families), or acted on their own or a sheriff's inclination to remove troublesome and frequent offenders to more convenient and perhaps salutary custody. To accommodate all interests, Young envisioned Spadra as both a hospital for "hopeful" cases and a separate work farm for incorrigibles. But a parsimonious Republican governor regarded Spadra as "a test tube experiment which we can later enlarge and expand." Thus one facility was asked to serve both functions. Moreover, the equally thrifty legislature located Spadra on land already owned by the state, an unfortunate site with no natural barriers to elopement. The result was large numbers of escapes-almost one per day through 1929-to which Joyce responded in time-honored fashion: $\mathrm{He}$ built higher walls, employed more guards, and installed a searchlight "that could detect escaping inmates at night over a distance of three-quarters of a mile." He also tried to educate superior court judges about suitable candidates for treatment: "We would welcome the man who has no criminal record or who has not lived on his wits or been the recipient of the proceeds of prostitution, or worse." Escapes finally were cut to about one per month, but the judges were hard to educate, so Joyce sought greater discretion for the superintendent, a tried 
and true way to dispose of undesirable patients. He got approval in principle in January 1931, a week before the Jost Bill was introduced in the Assembly. Joyce's enlarged discretion would allow him to refuse addicts who had failed in treatment at other state hospitals and those with criminal histories. This would substantially hamper the sheriffs, probation officers, and judges who would use Spadra as an alternative to the county jail or state prison. ${ }^{23}$

Such an exclusive approach to rehabilitation was controversial given its timing. An "intensive narcotics drive" in San Francisco had produced 424 drug arrests (with 350 convictions) between June 1930 and February 1931, along with hundreds of "vagrant addict" arrests. ${ }^{24}$ It was a terrible time for San Francisco's addicts, not only because of the heightened threat of arrest, but because supply was disrupted by the disorganization of a major dealing network. Anthony Votta, a long-time addict, recalled it later (from a New York jail cell) as "the biggest panic in the history of Frisco."

Cube morphine was in the market at that time, and what little of it was in circulation, the price went up from $\$ 1.50$ for about a three grain cube to $\$ 5.00$ per cube. . Men and women of all walks and stations in life roamed the city in search for this drug - night and day - and would pay any price. . . . Not being able to get the drug, we stormed the drug stores, and bought all the cough syrup that contained narcotics and drank the same. Some left the city, while others . . . actually kicked their habits upon their feet. . ...25

With legions of addicts already going "cold turkey" in jail, San Francisco's police court judges dismissed $95 \%$ of the "vag-addicts" who came before them. The San Francisco White Cross launched a drive to raise funds and promote medical alternatives to incarceration (including maintenance). And the Jost Bill proposed to put Spadra to wider use by allowing superior court judges to send to Spadra any addict convicted of possessing less than one ounce (roughly 437 grains) of morphine. Moreover, this option applied even to peddlers so long as they were addicts themselves and had 
been "entrapped . . by another addict acting as a stool pigeon for enforcement officers." The last provision was a slap at state and federal police methods, of course. ${ }^{26}$

Jost's attempt to commandeer Spadra for the jailers was extremely offensive to Young and Joyce (who called it "nothing short of a calamity"); but it was the Jost Bill's catholic provision for maintenance that set off alarms at the brandnew Federal Bureau of Narcotics. The bill was "a vicious piece of legislation," the seasoned agent Harry Smith advised Anslinger, "such as will tend to destroy much of the work . . . during the past twelve years" (i.e., since Webb). ${ }^{27}$ Relying on dubious evidence about the evils of the 1920 Los Angeles clinic supplied by Smith and Anslinger, Hearst's San Francisco Examiner excoriated the bill. Winifred Black Bonfils, writing in her prominent "Annie Laurie" column, warned her Hearst syndicate readers that the Los Angeles clinic "flooded [the state] with addicts, who rushed in here from all over the country." The Jost Bill would "invite every poor, wretched addict to California, and ask him to bring his friends and relations along." Smith recruited Earl Warren (1891-1974) to make similar dire predictions. Warren, later governor of California and then chief justice of the U.S. Supreme Court, was in 1931 the Alameda County District Attorney. ${ }^{28}$

The political bum's rush was effective. Unlike the 1920 Los Angeles clinic, the Jost Bill found no defenders in the press, and every authority condemned it in hair-raising terms. After a March 17th hearing, the Assembly Committee on Medical and Dental Laws unanimously tabled it. Jost pledged to cooperate with Young and Joyce to work out the apportionment of addicts among the jails, Spadra, and other state hospitals. But Spadra's problems in this respect were only beginning. ${ }^{29}$

The end of the LACMA clinic
On April 24, 1934, in what the Examiner called "a series of spectacular sorties," FBN agents arrested five physicians, four druggists, and a male nurse in different sections of 
greater Los Angeles. They had allegedly prescribed or conspired to furnish morphine to addicts in violation of the Harrison Act. Harry Smith, who coordinated the arrests, announced that they were the result of a continuing investigation of diversion from legitimate channels. ${ }^{30}$ A LACMA clinic doctor, Frank T. Cary, was among those arrested. The following day, the clinic's director and chair of LACMA's Narcotic Committee, Dr. Edward Huntington Williams (1868-1944), turned himself in. The arrests of Cary and Williams occurred only 10 days after the city health officer had persuaded the city council to resume modest stipends for the two clinic doctors, who had been volunteers since $1932 .{ }^{31}$

The city health officer, Dr. George Parrish (1872-1941), was a feisty veteran of acrimonious public battles with religious fundamentalists and health faddists, and he was not cowed. However, after the arrests he was hard-pressed to maintain the clinic, and he came under terrific pressure from the FBN and the Los Angeles police to acquiesce in seven onerous conditions for its continuation. These included provisions for the re-examination of all clinic patients as well as their fingerprinting, photographing, and registration with state and local narcotics police. Most important, a six-grain maximum daily allowance would be imposed. ${ }^{32}$

On May 11 Parrish met with federal and local representatives to discuss these terms. Harry Smith and the Los Angeles police chief insisted that such conditions were required by the Harrison Act. Parrish firmly disagreed, and he prevailed upon Dr. Edward H. Anthony (b. 1878), physician to federal prisoners in various area jails, to take over the clinic with health department financial support and political cover. With reluctance, which grew as federal agents and Los Angeles police began to harass him, Anthony served as the sole clinic doctor for seven weeks - until he and a cooperating druggist were arrested by the FBN for violating the conditions laid out by Smith, particularly that concerning the permissible daily ration. In spite of the mayor's remonstrations with Anslinger, 
that was the end of the clinic. But it was not the end of the arrests: On August 1 a federal grand jury indicted Williams and his office partner, Dr. Edson Hun Steele (1895-1953), on numerous counts of issuing "so-called prescriptions" in violation of Harrison and one count of conspiring to violate the law. ${ }^{33}$

Williams believed (correctly) that he was the FBN's principal target, but until Anthony was arrested, he was angry but not overly concerned. "The whole thing is one of the rankest and clumsiest frame-ups that I have ever seen," he wrote to Vollmer early in June. "And make no mistake-I intend to have the last laugh in this case." Williams's early confidence was based on a naive conviction that he would be supported by his medical peers and by the Roosevelt administration, but as the arrests of Los Angeles physicians continued throughout the spring and summer of 1934 , Williams began to take his position quite seriously. "The reign of terror now in progress to suppress medical men is without precedent," he wrote to Vollmer. A recently arrested physician, he reported, "gave morphine to a man who has cancer of the rectum as well as tuberculosis. The officers used him-this perfectly legitimate case, a dying man-as a stool pigeon." The purpose of his own arrest was clear to him: "The whole object of the attack seems to be to use me . . . so that the medical fraternity may be frightened into closing the Clinic and refusing to prescribe morphine." Williams recognized "the moving spirit[s] in this conspiracy" to be Sanborn Young ("a paranoid fanatic who has run wild"), and Harry Smith ("his actions indicate the grandiose ideas of paresis"). Williams's supporters had appealed directly to the secretary of the treasury, he told Vollmer, because "his Narcotic Department, headed by Anslinger, is not to be trusted." ${ }^{34}$

Williams was right to be suspicious of the FBN, for Harrison Act enforcers had been marking him since 1920, when he was a member of the Los Angeles clinic's advisory committee. His faith in his fellow physicians was misplaced, however. 
Although Williams had the private support of prominent members of the AMA and the California State Medical Association, neither of these organizations, nor even LACMA, was willing to come to his defense publicly. In part, this was because over the years the LACMA clinic became an organizational loose cannon. The Narcotic Committee was a presidentially appointed group with ill-defined responsibilities. Although it had 24 members in 1934, no more than a handful participated. As no regular reports were made on the clinic, few of the committee's own members knew much about it. When the FBN moved in the spring of 1934, LACMA's president was unaware of the clinic; in fact, he claimed that the Narcotic Committee "was never authorized by the County Medical Association to create a clinic or to enter into group treatment for addicts"- an activity of which he disapproved. Such controversy among LACMA's councillors about the clinic's history and legitimacy and, doubtless, real fear of the FBN produced caution, if not foot-dragging. Resolutions calling for a full hearing by the membership and for public support for the arrested doctors were voted down by LACMA's leadership. ${ }^{35}$

Although LACMA did not offer public support to Williams or to any of the arrested doctors, a special committee, comprised largely of past presidents of the organization, did try to intercede with the FBN. However, this committee's internal division about ambulatory treatment was exploited by FBN agents who systematically misrepresented clinic procedures and Williams's professional history. In meetings that agents characterized as confidential, the doctors were told, for example, that in May 1921 Williams was charged with "prescribing large quantities of narcotic drugs for 32 addicts, under the guise of so-called ambulatory treatment." The agents claimed that a federal grand jury warned Williams that if he failed to stop, "the case would be reopened." The doctors were informed further that in early 1928 Williams had been "reported for sending drugs through the malls to an addict physician," but that no action was taken because "the addict 
died." And apparently most damaging, in the eyes of at least one LACMA representative, Williams and Steele had prescribed for a dead man. ${ }^{36}$

When finally made aware of these claims in early 1935 , Williams called the first "an unmitigated, purposeful lie." No documentary evidence ever was produced to support the FBN's contention. In the matter of the addict physician sent drugs through the mail, Williams had an impressive and ironic rejoinder: The Pasadena doctor in question had at one time been former Treasury Secretary Andrew Mellon's family physician; he was brought to Williams "with the knowledge of the Secretary himself" because the old man was dying of cancer. With respect to prescriptions for the dead, Williams could not resist pointing out that prescribing for a dead man was perfectly legal. It was illegal, he continued, for a living person to use any such prescription-but no one had suggested that this had happened. He then detailed how the clinic doctors worked out with state narcotic officers, whom he named, a procedure for using a trusted addict-a man with advanced tuberculosis who was also a state informer-to fill prescriptions for clinic patients too sick to attend. He then delivered their morphine. The "dead man" was a patient who had died between the writing of the prescription and the morphine delivery. According to Williams, the courier "reported the situation and no more prescriptions were written." ${ }^{37}$

The interesting question is why the FBN worked so hard and played so rough to prosecute doctors connected with a clinic that made no claim to maintaining "mere" addicts. Williams did not support indiscriminate maintenance. Like most other maintenance advocates of this era, he regarded all forms of ambulatory treatment as second best to hospitalization and abstinence. Further, like Spadra superintendent Joyce, Williams distinguished "deserving and decent addicts" from those who were "dishonest and degenerate," the former deserving "great sympathy," the latter "permanent penitentiary residences." The LACMA clinic's patients were desper- 
ately sick by every account. Ample evidence was presented in court that some patients referred by physicians for clinic enrollment were refused after examination and laboratory work because Williams or one of his associates thought that hospital treatment was indicated. Why, then, were physicians at the LACMA clinic treated differently from doctors in, say, Pennsylvania, who maintained a similar population of addicts? ${ }^{38}$

There were several reasons. First, there was considerable symbolic value in bringing Edward Huntington Williams to heel. He was an associate editor of the 10th edition of the Encyclopedia Britannica; with his brother, Henry Smith Williams, he was also a prolific and well-known popular science writer. Second, he had been an outspoken opponent of the Harrison Act since its passage, arguing that the law should be repealed in favor of the medical management of addiction by the PHS. In a newspaper editorial that Anslinger brought to Assistant Treasury Secretary Gaston's attention, Williams was portrayed as a medical eminence and quoted as follows: "The peddler is the great problem of the drug situation. The Harrison Narcotic Law, by preventing doctors from prescribing morphine [to addicts], created the peddler. . . . There would be no peddlers now if that law were repealed. But that would throw the officers out of work." The editorialist concluded that "the Doctor's proposals have been attracting widespread attention. It is well to withhold judgment on the recent charges against him. ${ }^{39}$

But most inflammatory to Anslinger, Williams was not a lone dope doctor: He was associated with the White Cross, which was touting the LACMA clinic as a model for a revived maintenance movement. In fact, this connection was incidental; Williams was more an intellectual fellow traveler than a comrade in arms. Even so, explaining to Gaston why the FBN was proceeding against Williams, Anslinger emphasized that Williams was "connected with the International [San Francisco] White Cross," an organization "making a drive to 
repeal the Federal narcotic laws and to set up in their place a system . . under which licensed addicts are supplied with narcotics." Anslinger saw Williams, like the White Cross, as a brazen political enemy, and he intended to play Nemesis: "The moral effect of his conviction upon other practitioners," Anslinger wrote in a memo to himself, "will most certainly result in greater circumspection in the prescribing and dispensing of narcotic drugs along the West Coast." This was the motive Williams had asserted all along..$^{40}$

In their criminal trial, Williams and Cary hung their defense on Linder. The United States district attorney asserted that clinic patients paid Williams five dollars for a physical examination and then were referred to Cary "with an 'O.K.' for a morphine prescription," for which they paid an additional five dollars. However, the only evidence of such crass practice came from an addict of long standing brought from Chicago to work as an informer. The FBN paid him by the day and also gave him a "reward" following the arrest of Williams and Cary. The doctors' attorneys claimed that the FBN was maintaining the man on morphine so that he would testify (ironic proof that well-supplied addicts could function normally), and they insisted that he be kept in custody without drugs so that the jury could see him in withdrawal. The judge refused, but Williams's lawyer tried to keep the issue before the jury: When a pellet of morphine rolled off a scale during the testimony of a government chemist, he remarked that it "had better be given" to the informer. The judge held him in contempt.

After an acrimonious six-week trial in which all 17 medical experts supported the doctors, the judge instructed the jury that such professional testimony and the Linder standard of good faith were "advisory only." Told to rely on its "experience in human affairs," which is to say, on a common sense notably jaundiced on drug matters, the jury convicted Frank Cary on five counts of violating the Harrison Act. He was sentenced to 12 months in a federal road camp and five years' 
probation. Convicted on one count, Williams spent a year on federal probation and was forbidden to hold a narcotics license for two years. Their appeals were thwarted on technical grounds due to a filing error by their attomeys. Both doctors were acquitted of conspiracy. After three years, in July 1937, the FBN dropped charges against Williams and Steele. At about the same time, the FBN agent-in-charge who helped make the Williams-Steele case was arrested for selling a large quantity of morphine to gangsters. He pleaded guilty and went to prison. ${ }^{41}$

The trial of Edward Anthony and pharmacist William Dickinson resulted in a deadlocked jury, and the case was taken up for decision by Federal District Judge Leon R. Yankwich. Finding that Anthony acted in good faith by the Linder standard, Yankwich noted acerbically that "neither [Los Angeles Police] Chief Davis nor the federal authorities can give an ultimatum to a physician as to the manner of treatment by him . . the violation of which would constitute a violation of the law." Anthony, Yankwich asserted, lived up to his Hippocratic oath-and was then punished for doing so. In acquitting Anthony and Dickinson, Yankwich had the following message for the FBN: "It is not the law that a medical officer can give absolution for criminal offenses, any more than it is the law that the enforcement officers, by placing their own interpretation on the law, can create an offense which does not exist." ${ }^{42}$

$* \quad * \quad *$

Seven of the LACMA clinic's last 72 patients died shortly after the clinic closed - of pulmonary tuberculosis, diabetes, heart disease, advanced syphilis, all complicated by years of addiction and the therapeutic necessity of large doses of morphine. An eighth patient, a 40-year-old tubercular woman, went to work as an informer for the Los Angeles police and not long after was beaten to death on the job. Between May 29 and July 10,1934, of seven clinic patients committed to 
Spadra, six were quickly released by Superintendent Joyce because they were too sick to benefit from treatment. On February 26, 1937, a former clinic patient ended as follows an open letter to the major Los Angeles newspapers and the city's public officials: "Today I am without narcotics and am having [pulmonary] hemorrhages. Physicians will not prescribe narcotics for me as they fear arrest. . . . I have been refused treatment at the Spadra State Hospital. I have been refused admittance to the Los Angeles General Hospital because I am addicted. . . . I am not financially able to go to a private institution. Unless I receive narcotics I will die. Yours in distress. ${ }^{\prime 3}$

A debacle "I am commencing to work on the [San Francisco] White for the Cross," Sanborn Young wrote to Anslinger in March 1934, a San Francisco month before the first LACMA clinic doctors were arrested. White Cross Young knew that the San Francisco group, recently incorporated as the International White Cross as the result of conflict with the Seattle parent organization, was planning an independent fund-raising and membership drive in Southern California. The organization walked right into the "reign of terror" and found Young and Anslinger ready to exploit their estrangement from the founding chapter. By August, when Williams and Steele were indicted, the San Francisco or International White Cross was an outlaw among charities. ${ }^{44}$

The American White Cross Association on Drug Addictions was founded in Seattle in December 1920 by an Episcopal rector and four friends. Throughout its history the organization drew heavily on Protestant clerics for leadership and relied for sustenance on membership fees, the sale of White Cross postal seals, and small grants from the Seattle Community Fund. Despite attempts to establish other branches, only in San Francisco did the association take root outside of Seattle..$^{45}$ 
The San Francisco chapter was founded in 1927. Like the Seattle group, it did educational work, publishing and distributing literature and providing speakers on addiction, particularly in the schools; and it took an interest in treatment, arguing publicly for leaving the management of addiction to physicians. Its secretary worked with addicts who brought problems to the Market Street office, and doubtless she put jin a good word for them with local judges. In 1934 the director was Reverend James S. West, former pastor of San Francisco's First Baptist Church. ${ }^{46}$

Like its parent organization, the San Francisco White Cross raised money by soliciting memberships and selling postal seals. In 1932 it mounted its first membership and fund-raising drive in Southern California, systematically canvassing the residents of Los Angeles, Long Beach, and San Diego. Charitable organizations customarily sought approval by local philanthropic elites in advance of such campaigns. In San Francisco this meant review by the Indorsement Council, a private body closely connected to the Chamber of Commerce; in Los Angeles it was the Social Service Commission, a municipal body. The endorsement groups guarded against fraud; they also bounded political acceptability. Failure to seek their approval had no enforceable consequences, but it could result in crippling publicity. Perhaps out of ignorance, perhaps in defiance, in 1932 the White Cross did not go through the endorsement committees of the cities in which it solicited. The complaints about the membership drive were many and loud. Members of the Los Angeles Social Service Commission were themselves solicited by telephone, a practice its president considered "inherently crooked." When the White Cross returned for another campaign in the Southland in the spring of 1934 and applied for endorsement, commission members were primed to be critical. So was Sanborn Young, put on the FBN payroll by Anslinger at one dollar per year to serve as an official spokesman. And Young had mobilized his cadres: the Los Angeles police, the state Division of Narcotic Enforcement, the Los Angeles county jail physician, 
and the Los Angeles district attorney, among others. Young also got help from Everett G. Hoffman (1876-1953) and Earle Albert Rowell, Seattle White Cross stalwarts who confirmed reports of corruption in the 1932 campaign. Rowell told the Social Service Commission that of $\$ 7,500$ collected from Los Angeles residents, the organization had seen but $\$ 900$. The solicitors spent the rest on themselves. West, who had not been in charge at that time, conceded that this was true, but claimed that the organization had since "devised a system by which solicitors could not appropriate collections." His assertion was greeted skeptically. Given the previous ineptitude of the San Francisco White Cross and the improbable help of Hoffman and Rowell, Young and Anslinger easily executed their strategy to cripple the organization's ability to raise money. The Social Service Commission pounded the White Cross on technical matters and withheld its endorsement. ${ }^{47}$

Young also wanted to attack the group's ideas in a highly visible public forum. Therefore, instead of allowing the commission to confine the matter strictly to professional and technical considerations, Young and his allies tore into West with the extraordinary hostility they usually reserved for communists. After calling the organization's "teaching" nothing more than "the desire of the dope addict," Young continued: "It is a crying shame that our public schools are open to [the] vile educational propaganda that this organization . . . is espousing. Their theories are more dangerous to our school children than any pestilence." West was on his feet before Young finished. After defending himself as a father of three and a man of God, he invoked the First Amendment: "I have just as much right as Mr. Young to speak anywhere for a cause which I believe is just and right; any American citizen has that privilege." Before West could turn to matters of substance, however, Young regained the floor and launched a bitter attack on narcotic clinics. ${ }^{48}$ 
It was a rout. At one point or another in the several hearings held before large audiences from mid-June to mid-July, all three commissioners expressed their disagreement with White Cross doctrine, whether on modifying the Harrison Act to specifically permit clinics or on the question of whether addiction created "criminal desire," as one commissioner put it. Although the commission's decision was couched in technical terms, its repudiation of White Cross philosophy was clear. Even the Los Angeles Times, which had supported clinics in 1920 and was not given to fanning the flames of drug war, nonetheless augmented its approval of the commission's technical objections with an editorial condemnation of White Cross policy. ${ }^{49}$

The hearings before the Social Service Commission seem to have started the San Francisco White Cross on a steep decline, probably because it could no longer effectively raise money by its accustomed means in either Los Angeles or San Francisco. Although the White Cross was not campaigning in San Francisco and had no request pending, the Indorsement Council withdrew its support just as the Los Angeles Commission began hearings. ${ }^{50}$ The gratuitous quality of this action strongly suggests a political motive, and one suspects the intervention of Sanborn Young. In the event, when William Walker, a key commission witness hostile to the White Cross, embraced clinics a few years later, he looked for support to Seattle, not San Francisco.

The defection By late 1938, William G. Walker (1885-1956), chief of Caliof William fornia's Division of Narcotic Enforcement, was convinced Walker that Spadra was a failure and that federal morphine dispensaries made more sense. At a December 6 budget hearing held by governor-elect Culbert Olson, Walker said this publicly for the first time. He pronounced Spadra "a useless expense" and proposed that "addicts be registered, fingerprinted, examined and then permitted Government rations . . . according to need, with doses gradually decreasing to a minimum." His statement made news all over the country. "I told him the 
truth," Walker wrote subsequently to a Washington state senator and White Cross advocate. "[W]e have a problem of incurable people on our hands that cannot be cured by ordinary methods. . . There certainly is a better plan than arresting the addicts time and time again, only to have them contact peddlers immediately on their release. If anyone could see the suffering of these poor devils while withdrawal symptoms are present, they would understand why we should have a change." ${ }^{51}$

This extraordinary admission came from a teetotaler with solid credentials in police work: In addition to running California's prohibition administration from 1920 through 1932, Walker had been a highly regarded chief of police in Fresno for five years, taking that position when his predecessor and 13 other officers were arrested for prohibition violations. He was on cordial terms with Anslinger, and Anslinger had praised his appointment to division chief to Sanborn Young. ${ }^{52}$

It is not clear exactly when Walker became an apostate. He was appointed chief in July 1933, after the division had been mired in controversy, declining morale, and an economizing legislative attempt to do away with it and leave all drug law enforcement to local police and the FBN. (Only massive Hearst protests and Anslinger's intervention prevented this.) Through the mid-1930s, certainly, Walker hewed to the conventional line. In November 1933, as part of the Hearst papers'campaign to defend state and federal enforcement budgets, Walker cooperated with a reporter in the fabrication of a morphine and white-slave-trade story that was a sensational item-until the San Francisco News revealed it to be bogus. Throughout 1934 he helped Young and Anslinger discredit the San Francisco White Cross. As late as 1935 he faithfully intoned the "murder weed" characterization of marijuana that was becoming part of the orthodox canon. In 1937, however, Walker split with Young. They had serious differences over the potential menace of marijuana, the wis- 
dom of the federal Marijuana Tax Act of 1937, and the danger of Asian morphine to the Pacific Coast. But they came into sharpest conflict about the utility of Spadra. By 1937 Spadra had been in political trouble for several years, and Walker sided with its critics. ${ }^{53}$

In March 1931, seeking to head off Jost, Young had promised: "Give us two years more in the handling through hospitalization of the narcotic addict and . . . California will solve the problem of whether or not the addict as such can be permanently cured." He was optimistic: In early 1931 Spadra not only held its capacity of 95 but was referring patients to nearby state hospitals. Superintendent Joyce may not have been getting exactly the sort of patients he wanted, but he had gained significant control over admissions and business was booming. By November 1933, however, Spadra's census was 55 and slipping. Joyce's assistant told a visiting Hearst reporter: "The only explanation I can find is that the narcotic enforcement bureaus have been so reduced in personnel and funds that they cannot . . . bring in the dope victims for treatment." As this was in the midst of the aforementioned funding drive, it was an obliging assessment and superficially plausible: The division's budget had been cut dramatically. But according to Walker, this impaired only the pursuit of substantial peddlers, a job the division shared with the FBN. It did not affect the apprehension of addicts eligible for Spadra, most of whom were arrested by local narcotic squads and came from county jails. The state's director of institutions got it right when he blamed Spadra's declining census on economies "adopted by many counties." Obliged to pay $\$ 25$ per month for each addict committed to Spadra, as well as to absorb the cost of transportation and accompaniment, most counties stopped making commitments or made them rarely. Once the Depression matured, the teeming county jails had to serve. By the end of 1934, Spadra's census was down to 45; by October 1937, it was 17. Like his good 
friend Herbert Hoover, Young had not reckoned with the consequences of protracted hard times. ${ }^{54}$

Spadra's falling census jeopardized its survival. Indeed, only Anslinger's direct intervention and the vocal support of Spadra's traditional constituencies (particularly women's groups and the Hearst papers) persuaded Governor James Rolph against scrapping the hospital late in 1932. But although Rolph had been won over, his administration was paralyzed by the Depression and financial scandal. As it happened, Rolph became mortally ill early in 1934 and died on June 2, but it was apparent much earlier that he would not be a gubernatorial candidate again. By January 1934, with only 50 patients at Spadra, Young knew that he needed a plan to keep the hospital alive under a new governor. ${ }^{55}$

One proposal, floated by Young at the first of the year, was to have state and federal narcotics officers "pick up addicts that meet the requirements of the officials in charge of Spadra." Walker did not object to this rather desperate plan, but he reminded Anslinger that because the state had very few enforcement officers, the burden of its achievement would be largely on the FBN. He then reiterated Spadra's desire to avoid "the habitual criminal or 'alley hype' type, or incurables." There is no record of Anslinger's response, but regardless of his support for Young, it is inconceivable that he would have allowed his own relatively small force of agents to be sent out to rustle up worthy young patients for Spadra. ${ }^{56}$

Harry Smith forwarded to Anslinger a next-best proposal: Spadra could be used as a probationary alternative to prison for selected federal drug offenders. This was to be one function of the federal narcotic hospital at Lexington, Kentucky, authorized by Congress in 1929 but not due to open until 1935. Smith made a creative pitch to get Spadra a piece of this market, and Anslinger sent the idea to the director of the Federal Bureau of Prisons, who pursued the matter with 
Joyce. No agreement was reached, however, probably because no statutory mechanism allowed the commitment of federal criminal offenders to a state hospital. ${ }^{57}$

As these ideas were being discussed, Spadra's chief parole officer returned bad news. Spadra's "cure rate"-that is, the percentage of addicts abstinent two years after release-was just under $18 \%$ for $1928-31$, and this did not include in the denominator "the escaped or the unsuitable cases that were discharged or returned to court." Young found this a "great disappointment," but he was forthright about the carefully collected data: "It is convincing evidence," he wrote to Anslinger, "that the hospital alone is not a success, that the farm in connection with it for incurables is an absolute necessity. . . . At present we have more than five hundred addicts on our streets that have been given the cure at a cost of almost $\$ 1,000$ each and are still stealing and begging and a source of great expense to us." Lexington, he thought, had better profit from Spadra's experience or it "will make no better record." ${ }^{58}$

A "farm" or "colony" for the incarceration of addicts for three, five, or perhaps even 10 years, as Young and Joyce favored, was not the only logical response to such a concession. However, it was consistent with the orthodox views that only permanent abstinence counted as therapeutic success, and that incarceration had a powerful preventive effect because addicts were relentless proselytizers. The colony plan also fit Young's reluctant conclusion that the only addicts Spadra could get were "just the kind which we can not help." Thus the promotion of addict colonization, envisioned in Spadra's original design, became fundamental to Young's strategy to keep Spadra open. The hospital would now be sold as a way to reduce crime and the spread of addiction via specific deterrence. Regardless of what it was called, Spadra would now be marketed as a prison. ${ }^{59}$ 
Maintenance advocates took a different lesson from their pessimism, emphasizing the management rather than the cure of addiction. Still, while maintenance was sharply at odds with the Treasury Department's obsession with supply reduction and the FBN's consequent persecution of physicians, it was not inconsistent with tough law enforcement. George Parrish, for example, favored a "clinic-hospital and legal plan." This combined maintenance clinics (to reduce illicit traffic) with involuntary institutional treatment of six months to two years (for addicts motivated to be "cured" or addicts caught peddling), followed by welfare and vocational support as needed. These efforts were to be combined with a federal law that imposed on non-addicted smugglers or peddlers "a minimum penalty of such uniform severity . . . that no one would or could try it twice." This was roughly the position of the White Cross, and it seems to be the view at which Walker arrived. Although Walker supported maintenance, he also asked Olson for more enforcement money; and although he regarded Spadra as a failure, he was happy to have addicts sent to the new federal hospitals opened at Lexington (in 1935) and Fort Worth (in 1938), albeit because they were federally supported. ${ }^{\circ}$

For his candor, Walker endured a month-long blitz of wellorchestrated villification. The Hearst papers dusted off their earlier warnings about clinics as migration magnets, recalled the spectre of the disgraced Jost Bill, and, disregarding the stricter commitment requirements achieved by Young and Joyce, claimed that Spadra was curing addicts "of the worst type," thus putting its low cure rate in a novel light. Young publicly characterized Walker as an inefficient administrator who put politics above integrity, and called his ideas about clinics "ridiculous." Anslinger provided unsubstantiated information that, with suitable embellishment by San Francisco judge Twain Michelsen, was used to characterize Walker as a cynical failed federal-job seeker looking to curry favor with the new governor. Michelsen, whose vitriol sometimes raised even Young's eyebrows, accused Walker of 
catering to the "perverted tastes" of criminals. The California Federation of Women's Clubs and its various chapters weighed in with petitions denouncing Walker, as did the still redoubtable Women's Christian Temperance Union. In all, it was a loud and long public hiding. "Maybe that will teach Mr. Walker not to stick his neck out so far," Assistant Secretary Gaston wrote to Anslinger approvingly. ${ }^{61}$

By February 1939 it was apparent that Olson, although he favored state control of wholesale and retail liquor distribution, intended neither to support morphine clinics nor to retain Walker. Young, planning an anti-narcotic exhibit for the San Francisco World Fair, nonetheless wanted to press the assault. Anslinger advised against it now that Walker had lost. "One of the most effective weapons against these agitators is not to dignify their arguments by taking them too seriously," Anslinger wrote. "Walker is a skunk and we have all learned from childhood never to engage in a battle with that animal. They usually go into seclusion by themselves." ${ }^{2}$

William Walker returned to Fresno and sold real estate. However, as Young feared, Walker's defection had doomed Spadra. Olson never made appointments to the hospital's advisory board, and he pocketed a successful colonization bill because his new director of institutions, Los Angeles psychiatrist Aaron Rosanoff, was determined to relieve the state of Spadra's cost. Failing to get Anslinger's help in negotiating the systematic commitment of California's addicts to the federal hospitals, Rosanoff closed Spadra over the noisy protest of its political friends. The institution's few remaining patients were distributed to other state hospitals on June 28 , $1941 . .^{63}$

A letter from In April 1940 a veteran Oakland police officer, Frederick Friend Earl Barbeau, told a Fresno gathering of the Women Peace Officers Association that narcotic clinics or a wholesale supply plan would stop "the illegal sale of . . . narcotics and would take care of the old addicts and reduce addiction 90 per 
cent. The old addicts are the ones who start the new ones," Barbeau explained, "and by stopping the illegal traffic and registering all the users we could make great progress in controlling this age-old curse." There was no "cure" for addiction, he averred. ${ }^{64}$

Among his auditors was a California State Federation of Women's Clubs worker who was sufficiently scandalized to write immediately to Twain Michelsen. Michelsen replied that Barbeau was spreading "the propaganda of the notorious White Cross." Michelsen was actually less concerned with the White Cross than with August Vollmer, whose views Barbeau seemed to be promoting. Michelsen wrote to Anslinger about Barbeau's address and included a sheet on which he typed selected offensive passages from Vollmer's The Police in Modern Society (1936). He recommended "constructive protest" of the officer's remarks. Anslinger already knew about the speech because the FBN district supervisor in San Francisco had sent him a clipping from the Fresno Bee that summarized it. The supervisor intended "to have a little talk" with Barbeau "to convince him of the impracticability of such a procedure." 65

Anslinger's San Francisco man never contacted Barbeau, and the matter might have ended there except that in September 1940, at the convention of the International Association of Chiefs of Police, Harry Smith took matters into his own hands, approaching the police chief whom he took to be Barbeau's boss. As it happened, Barbeau's association with Vollmer, formerly the Berkeley chief, caused Smith to accost the wrong man. Barbeau was an Oakland officer, and the Berkeley chief had no idea who Smith was talking about. (He subsequently sent Anslinger a list of Berkeley officers so that he might identify the man.) Smith contacted his old friend Earl Warren for help. Warren, by then California's attorney general, had been the district attorney in Alameda County (where Oakland and Berkeley are located) and had helped Smith derail the Jost Bill in 1931. Warren did indeed know 
Barbeau, and he assured Smith that he would "do whatever I can to bring about a change in his views." On October 1 Warren wrote Barbeau a letter worth quoting at length:

I have just received a letter, a copy of which is enclosed, from Harry D. Smith. . . . As you will observe . . . his Bureau is somewhat disturbed because of your recent address at Fresno. Of course, it is no concern of mine except that all of us are interested in sound and effective narcotic control. Evidently your views on the subject have been cited in other parts of the country, which is the reason for his writing to me.

I know you have given a lot of thought to the subject and I presume that if you are correctly quoted it is your considered opinion that clinics of this character would bring about more effective control. I have never thought that it [sic] would do so but I realize that whenever we are in the field of speculation, reasonable persons will differ. After reading Mr. Smith's letter I wondered if perhaps reconcilement of your views and those of the Federal Bureau might not be effected by a conference between one of its representatives and yourself. I would be glad to endeavor to arrange such a meeting if agreeable to you.

I am sure that you will understand that I do not consider this a matter of official business as conflicting views on law enforcement methods are peculiarly personal. However, where mutual friends in the law enforcement business disagree on policies of vital importance, I presume it is not out of order as a friend to suggest something that may bring them together. It is in this spirit that I am writing to you and with full realization that conflicting views have been honestly and sincerely arrived at.

I am sorry that I do not get an opportunity to see the boys in the Oakland department more often but this job takes me away from the Bay district so much that I have very little opportunity to do more than sleep there. ${ }^{66}$

Barbeau was suitably impressed but also savvy. Rather than treating the letter as a personal matter, he did not reply until he had discussed it with his boss. On October 8 he wrote to "Dear Friend Earl" that he would be "only too glad to meet any member of the Federal Bureau to talk things over." He continued: "As for the article in the Fresno Bee, . . . they did not particularly mis-quote me but they did not fully quote 
me[,] which made a lot of difference as to meaning. I hope you dont [sic] feel that I have changed my mind to any degree as to law enforcement work, far be it from such." Warren sent Barbeau's reply to Smith, suggesting that "sometime when either you or some ranking officer of the Bureau is in this part of the country you arrange to sit down with Fred and discuss the entire subject." Then, in conclusion, he interposed himself, noting that such "an informal discussion" would "help bring me up to date on narcotic enforcement and give me an opportunity to see old friends again." ${ }^{67}$

Warren simultaneously put Barbeau on notice, handed him an out (misquotation), and refused to let him face the FBN without himself as intermediary. He achieved the FBN's goal of silencing Barbeau without allowing one of his "boys" to be bullied. It was neat work. Smith wrote Anslinger that he was immensely "gratified" by "such prompt and cooperative action," characterizing Warren's letter as "a master-piece of diplomacy . . . [that] without doubt will attain the desired ends." "However," he closed, "if there should be any repetition, and you will let me know, I have still other ways of attending to the matter." ${ }^{68}$

"Lindesmith's There is a last episode to consider. At the 1940 police chiefs" Mythology" convention where Harry Smith inquired about Fred Barbeau, a former New York City police official gave Anslinger a copy of the July-August issue of The Journal of Criminal Law and Criminology. This contained "Dope Fiend Mythology" by social psychologist Alfred Lindesmith (1905-91). The article was a passionate dissent from American drug policy and the practice of demonizing addicts. Its last paragraph read:

The "dope fiend" mythology serves . . . as a rationalization of the status quo. It is a body of superstition, half-truths, and misinformation which bolsters up an indefensible repressive law, the victims of which are in no position to protest. The treatment of addicts in the United States today is on no higher plane than the persecution of witches in other ages, and like the latter it is to be hoped that it will soon become merely another dark chapter of history. ${ }^{69}$ 
Anslinger was not pleased. "It is unfortunate that an article containing such misinformation and half-truths should be carried in a magazine devoted to the education of law enforcement officers," he wrote to Assistant Secretary Gaston upon his return from the convention. He went on to lump Lindesmith with Vollmer (whom Lindesmith cited) and others with "similar views as to the ambulatory treatment of drug addicts." In keeping with his earlier advice to Young about the World Fair exhibit, Anslinger continued: "I do not wish to place the Bureau on the level of having to answer Lindesmith, and would like your suggestions as to counteracting this vicious propaganda." Gaston responded that "Lindesmith's piece is an apology for addiction written from the standpoint of an addict. We ought to look for a college professor, ex[-]district attorney or other lawyer or law professor to answer him."”o

Anslinger decided on Twain Michelsen, who hammered out a bellicose, several-thousand-words assault on Lindesmith, the White Cross, and particularly the World Narcotics Research Foundation (WNRF), a Los Angeles-based pro-maintenance organization to which Lindesmith, the Williams brothers, William Walker, and numerous other veterans of dissent had lent their names at the end of 1938. "Lindesmith's Mythology" outlined a conspiracy against the noble but beleaguered FBN, taking up 26 pages in the same journal that had devoted 10 pages to Lindesmith. Its last sentence captures its tone: "Neither narcotic monopolies nor narcotic clinics, with their 'low cost legitimate drugs,' as advocated by Dr. Lindesmith, will be permitted to gain a foothold in America as long as we have the protection of such dynamic agencies as . . . the Federal Bureau of Narcotics, nor will any narcotic racket of the pseudo-scientist be permitted to flourish in our midst." 1

This was published only months after an FBN agent, insisting that Lindesmith belonged to a "criminal organization" (the WNRF), had threatened him with the loss of his teaching 
position at Indiana University. As Lindesmith recalled the encounter in 1965:

He intimated that I might jeopardize my position . . . by expressing my views and expressed the opinion that I was unfit to teach. I sought to defend my position and indicated that $I$ thought British methods of handling the drug problem [by physician prescribing] were more sensible and effective than our own. He replied that I was living in the United States, not in England, that he didn't like the "damned Limeys" anyway, and that loyal citizens ought not criticize existing laws or policies of the government.

Later a second agent, sent in part to apologize for the threats of the first, explained to the incredulous professor that the FBN, in addition to enforcing the criminal law, "also had the duty of "disseminating right information and preventing the dissemination of wrong information.' "'

\section{Conclusion}

To stay experimentation in things social and economic is a grave responsibility. . . . It is one of the happy incidents of the federal system that a single courageous State may, if its citizens choose, serve as a laboratory; and try novel social and economic experiments without risk to the rest of the country. This Court has the power to prevent an experiment. . . But in the exercise of this high power, we must be ever on our guard, lest we erect our prejudices into legal principles. (Louis D. Brandeis, March 21, 1932) ${ }^{73}$

Irene Danford was a San Francisco area club woman. In the mid-1920s she went through several surgeries and in the course of managing "unbearable pain" became addicted to morphine. In 1928 she spent eight months in Patton State Hospital in Southern California; in 1929 she was four months at Agnews State Hospital near San Jose. In both cases she was discharged as "cured." But in February 1930 Mrs. Danford was arrested for forging prescriptions and was sent to Spadra. She was released in December, "cured" once more. In May 1931 she was again arrested for forging prescriptions. The federal judge, who usually dispensed five-year sentences 
to repeat Harrison offenders, let Mrs. Danford off with a three-year term in an institution to be chosen by the state attorney general. He would recommend parole after a year, he said, "if she had overcome the dope habit."

The judge's lenience reflected a diligent effort to match punishment to offender, to yoke the law to social custom. Mrs. Danford was in most ways absolutely respectable. She was an educated woman of high social standing, "an involuntary slave of the dope habit," according to her attorney, "having acquired it through sickness." Pleading guilty, Mrs. Danford insisted that she "adored her children" and "had never harmed any one" in her life. "It is difficult to associate with law breakers," she confessed to the judge. I do not know how to get narcotics from peddlers so I adopted the only method I knew to get them." Here indeed was an innocent; and here as well was a three-time loser who confounded those who would help her. ${ }^{75}$

Before Harrison, Mrs. Danford might have been discreetly maintained by her physician, had that been her choice. The California State Board of Pharmacy was forbearing and flexible in such matters, especially for reputable addicts. But by the 1920s Harrison Act enforcement put a great burden on doctors to justify maintenance, especially in cases like Mrs. Danford's, for she did not require morphine to sustain her life, but merely to manage pain and withdrawal. Only a liberal interpretation of medical necessity would have put her doctor on the safe side of Harrison, a law that Treasury had never interpreted liberally.

Mrs. Danford was the kind of "victim" championed by the White Cross, which struggled to introduce the public to representations of "normal" addicts: ordinary working people who were not "dope fiends." Maintenance advocates, after all, could not make the predatory "dope fiend," the sinister poster child of repressive policy, represent the possibility of benign (or less than catastrophic) opiate dependence any more than 
pension advocates could use an old soak of a tramp to advertise the Social Security Act. Conflict about morphine maintenance in the 1930s was also and inevitably about the public representation of addicts. There was no recourse to authoritative science: The durability of addiction was mysterious; its secretive nature and the primitive epidemiology of the era made it impossible to know much about how many addicts there were and what they were like on the whole. However, as Lindesmith recognized, empirical evidence was beside the point for the FBN because the demonization of addicts was critical to the maintenance of orthodoxy. The White Cross's evidence was better only in the sense that it effectively disputed FBN assertions about the addict's inherent depravity. The White Cross's normalization of addiction is best understood as a plausible but essentially rhetorical counterpoint to orthodox claims. ${ }^{76}$

On the other hand, there was little conflict about curability: By the mid-1930s, both supporters of maintenance and its orthodox critics believed most addicts to be incurable. Public Health Service doctors would be more optimistic until the end of the 1940s, however, and the PHS's Dr. Lawrence Kolb probably was more optimistic than most. Unlike Young, Anslinger, and even Thomas Joyce, all of whom tended to characterize addicts in blunt demographic and social terms, Kolb was subtle and clinically attuned. He sent Anslinger a particularly revealing comment on Anthony Votta, the Rikers Island epistler from whom we heard at earlier points in this narrative. Votta was a South Philadelphia Italian, a man of 41 (in 1939), addicted from the age of 18, a career "hype" and shoplifter, arrested 90 times by his own count. Votta was convinced of the injustice and folly of his 20-month sentence for possession of heroin. "I know," he wrote, "that I would live a much happier and longer life if I could get it according to law." In Anslinger's view, Votta was a typical "dope fiend." But here are Kolb's observations: 
[I]t is quite obvious that he is an incurable case . . . because he knows that he cannot be cured, and obviously does not intend to cooperate in efforts made to help him. I am quite in agreement with him that punishment is useless in his case, and doubtless irrational. . . Nevertheless, every addict is not like Mr. Votta, and it would require an extensive machinery honestly to separate hopeless cases like his from other cases for whom repression in the way of strict regulation, along with scientific treatment, might do good..$^{78}$

As Kolb appreciated, under the regime proposed by Votta a determination of incurability would confer a valuable privilege (maintenance), and thus there would be considerable incentive for addicts to be so diagnosed, including those who might succeed in "scientific treatment." While conceding that the Harrison Act "has not improved [Mr. Votta] at all," Kolb shared Anslinger's opinion that "in practical application" maintenance schemes ran the great risk of providing narcotics "to persons who, unlike Mr. Votta, might be cured." To separate "honestly" the curable from the hopeless, it would be essential to rely on evidence that could not be manipulated by the individual whose qualifying condition was to be verified. But clearly no test of an addict's incurability could meet such a standard, for, as Kolb observed, incurability was "a state of mind," specifically, the addict's own assumption of incurability, expressed in confessional terms and by a lack of cooperation in treatment. ${ }^{79}$

In the absence of a reliable validation mechanism, "an extensive machinery" would be required to enforce some workable surrogate. The FBN and a few states already had gone part way down this road by codifying exemptions from anti-maintenance policy, but these terms of exception turned out to be ambiguous and often arbitrary. It simply was not clear what complex combinations of disease and age made withdrawal from morphine life-threatening or cruel. Nor was there any established norm of endurance to apply to sufferers of intractable pain, even if it were possible to validate pain. How to measure cruelty? Nothing, it seemed, would substitute for medical judgment, and yet it was just such discretion 
that Harrison enforcers so mistrusted. After Webb, as morphine maintenance became hedged with limitations and made perilous by an imperious police power, doctors feared to err on the side of relieving simple suffering. The result was that some addicts died, coughing up blood in buckets like so many unattended paupers in a Victorian pesthouse.

In the age of methadone, one is struck by the severity of Kolb's standard; and indeed, by 1955 Kolb supported widely expanded, maintenance. In the 1930 s, however, orthodox reasoning about addiction was dominated by the antinomy firmly established by the 19th-century temperance movement: The confirmed, habitual user could be either abstinent or abjectly enslaved. Intermittent abstinence was a species of failure, not a kind of success. Nor was there readily intelligible language in which to represent the drug dependence of people who suffered no necessary gross incapacity. This put maintenance supporters at a distinct disadvantage. No matter how carefully the Williams brothers, for example, explained that morphine was not intrinsically harmful, and that addiction could be managed without horrible consequences, they seemed to be temporizing with (if not encouraging) an obvious evil. The Williams brothers clearly recognized that the maintenance of law-abiding addicts would promote many practices associated today with "harm reduction" (disinfecting and dressing abscesses, discouraging needle sharing, and promoting an addict's nutrition and overall health), but along with ambulatory treatment, these practices were tainted as tending to cater to vice by making it a sustainable project. Therapeutic orthodoxy had become rooted in deterrence by punishment, whether by human law or as the "natural" result of transgression. Dissidents argued that a history of addiction, combined with documented failures to remain abstinent after treatment and a defeated or defiant attitude about cure, should be adequate indication that maintenance was a more useful course than institutionalization. They were untroubled by the moral hazard posed by Kolb and would have made physicians 
responsible for managing registered addicts, the practice in England after 1926. Institutions would have been for those who wished to enter them.

If American federalism were thoroughly Brandeisian, federal authorities might have viewed the approach of the White Cross or the activities of the Los Angeles clinics of 1920 and 1934 as useful, even welcome experiments in social policy. But American federalism is selectively Brandeisian. The famous metaphor of the state as the laboratory of democracy is neglected or invoked throughout the political spectrum as strategy on a particular issue dictates. The decentralization of authority is a double-edged sword, and like that weapon it is a means, not an end.

From the beginning, Harrison Act enforcers in the Treasury Department rejected an experimental approach to treatment policy. The presiding strategy was to keep the development of treatment completely subordinate to iron-fisted supplycontrol measures, the consequences for addicts notwithstanding. State legislatures and citizens' groups were to support and carry out this federal policy, not criticize or innovate. Experimentation was an evil portent of backsliding into an era of lax regulation, not an opportunity to address the problems of regulation itself. Harry Anslinger inherited this staunchly prohibitionist organizational culture with its antimaintenance prejudice "erected into legal principle" in the form of Webb. Under Anslinger, the culture of the FBN was shaped by long-time Treasury men like Harry Smith. They were honest, loyal-and narrow. A few, like Smith, came from families bruised by addiction, and their work was intensely personal. They knew "wrong information," if not the First Amendment. ${ }^{80}$ 
Anslinger shifted the FBN's attention toward peddlers and away from street addicts, but despite his post-appointment rhetoric, he enforced no perceptible new dispensation for physicians who in good faith relieved the suffering of addicts. He had no inclination to re-examine evidence from the clinic era, accepting uncritically the official tale of universal ineffectiveness and corruption. Perhaps most important, Anslinger, like his predecessor, ignored Linder, engaging in a bold unstated policy of "agency nonacquiescence" with the judicial branch. This permitted the FBN's "lusty applications" of its police power to be driven by administrative regulations and its preferred judicial precedent of Webb. Anslinger knew that an acquittal achieved by a physician at a dear price was as good as a conviction when it came to frightening others. By such means, the FBN in effect regulated an area of medical practice that doctors were not anxious to reclaim. ${ }^{81}$

This is not to say that Anslinger discouraged the medical treatment of addicts. Treatment was important to the FBN because it helped make tough law enforcement politically palatable and kept the agency in tune with important constituencies like the Women's Christian Temperance Union and the array of influential women's clubs throughout the country. Cure, though, was less important to Anslinger than the surety of therapeutic custody as a specific deterrent. It was the "free and perambulating addict" whom Anslinger wanted to corral-whether in hospital or jail made little difference to him. Indeed, the more the hospital was like a jail, the better he liked it. A narcotic clinic, on the other hand, was more anathema than a writ of habeas corpus. ${ }^{82}$

For decades this view of treatment was rarely challenged, but in 1958, after three years of study, an interdisciplinary panel of experts issued Narcotic Drugs: Interim Report of the Joint Committee of the American Bar Association and the American Medical Association on Narcotic Drugs. The Interim Report raised the usual objections to orthodoxy and went so 
far as to recommend the creation of experimental outpatient clinics that might supply addicts under strict controls. Anslinger promptly organized his own advisory committee, which, in Comments on Narcotic Drugs (also 1958), countered that clinics were demonstrated failures, sources of addiction, and threats to national defense (they would abet World Communism's destruction of democracy's capacity to resist). Comments even allowed Twain Michelsen to reprise his role in the Lindesmith affair, which he did with relish, summarizing his earlier attack on villains past and updating it to light anew into Lindesmith, the now traitorous Lawrence Kolb, Rufus King (of the American Bar Association), and the "free-spending," irresponsibly liberal Russell Sage Foundation. The Interim Report, Michelsen complained, was "a libel upon the intelligence of the people of America." Surely it remained true that "only under the impact of heavy prison sentences can we hope to rout the scum of the criminal world." 83

For all its belligerence, the FBN did not radically alter the treatment of opiate addicts in California during the Depression. Anti-maintenance sentiment had been entrenched in medical circles for at least a decade before the Jost Bill, and despite men like Vollmer, Walker, and Barbeau, law enforcement officials probably were no more sympathetic even when substantially more frustrated. The ideological battle for organized opiate maintenance was lost in the few years following $W e b b$, not in the 1930s. More materially, absent the stimulation of federal funds proposed in the failed France Bill of 1919, public drug-treatment innovations were not politically feasible in California during the Depression. Not even the small, politically well-connected State Narcotic Hospital at Spadra could survive the state's financial collapse. Despite the New Deal, bond issues, and the adoption in 1935 of a controversial state personal income tax and a revised scheme 
of corporate taxation, California's governments remained cash-starved. With 700,000 unemployed by mid-1932, the state legislature stiffened residence requirements for public assistance, and the cities made themselves as unattractive as possible to the impecunious. Indeed, as the "migration magnet" rhetoric aimed at the Jost Bill suggests, the Depression greatly aggravated county governments' long-standing terror of vagrant undesirables and the fiscal burden of providing for newly arrived poor folk. In the infamous, short-lived "bum blockade" of February 1936, Los Angeles Police Chief Davis deployed 150 officers to seal the state's borders! $!^{84}$

Still, by dogging physicians and stifling public debate about maintenance, the FBN ensured that there would be no working models, no matter how modest, upon which dissent might build. As the LACMA clinic case shows, Anslinger fully understood the importance of vigilance. When crossed in such ways, the FBN and its allies did not merely defend their position by appeal to science and reason in public forums, nor did they stop at the political strong-arming that so infuriated conservative opponents of the New Deal when undertaken in more controversial areas of social policy. Rather, the FBN harassed, intimidated, and occasionally jailed detractors like so many feckless "dope fiends" or scheming "reds." Nonconforming organizations were not just contrary, they were "illegal." Functioning with little political restraint given the profound bipartisan consensus on drug policy and crime, the FBN carefully marked and strictly defended the boundaries of therapeutic orthodoxy. And beyond these lay dragons-or, at any rate, federal narcotics agents. 
Abbreviations used in notes for manuscript collections and names of archives:

AP: Harry J. Anslinger Papers, Pattee Labor Library, Pennsylvania State University, State College, PA.

CSA: California State Archives, Sacramento, CA.

DEA: Department of Justice, Record Group 170, Records of the Bureau of Narcotics, Drug Enforcement Administration, Pentagon City, VA. (Most of these records are now available at the National Archives Record Center, College Park, MD, but they are cited here as catalogued at the DEA.)

FDR: Franklin Delano Roosevelt Library, Hyde Park, NY.

LACMA: Archives of the Los Angeles County Medical Association, Los Angeles, CA.

LP: Alfred R. Lindesmith Papers, held by Dr. John Galliher, Department of Sociology, University of Missouri-Columbia.

PHS: Public Health Service, Record Group 90, National Archives, Washington, DC.

RP: James Rolph Papers, California Historical Society, San Francisco, CA.

VP: August Vollmer Papers, Bancroft Library, University of California, Berkeley, CA.

Notes 1. [Harry J. Anslinger], "The Fallacy of Narcotic Clinics," AP, Box 8, File 4; George Parrish, in "Institutions for Morphin[e] and Other Addiction-Forming Drugs," an open forum in California and Western Medicine, 43 (1935), 368-70 (quoted remark, 369).

2. "Editorial Notes," Pacific Pharmacist, 1 (1907), 65-7 (cited passage, 66-7). The editorial was in praise of the State Board of Pharmacy's Los Angeles crackdown on unlicensed purveyors and druggists "selling habit-forming drugs to 'fiends,' "On the confluence of temperance and professional influence, see Joseph F. Spillane, "Making a Modern Drug: The Manufacture, Sale, and Control of Cocaine in the United States, 1880-1920," in Paul Gootenberg, Cocaine: Global Histories (New York: Routledge, 1999), 27-34 especially. 
3. On the APhA model act: David F. Musto, The American Disease: Origins of Narcotic Control (New York: Oxford University Press, 1987), 17-8, 22. On California: Statutes of California, Thirty-Eighth Session (1909), Chapter 279, Section 8; Statutes of California, Forty-Third Session (1919), Chapter 612, Section $81 / 2$. The California "good faith" standard influenced Harrison enforcement from the outset; for its incorporation into Treasury regulations, see Charles E. Terry and Mildred Pellens, The Opium Problem (New York: Bureau of Social Hygiene, 1928), 758.

4. Musto, note 3, 121-6; quoted passage, 125-6. A fairminded discussion of the complexities of "ambulatory treatment" is Edward Huntington Williams, Opiate Addiction: Its Handling and Treatment (New York: Macmillan, 1922), 17-93. The asylum model in the treatment of alcoholism: Jim Baumohl, "Inebriate Institutions in North America, 1840-1920," in Cheryl Krasnick Warsh, ed., Drink in Canada (Montreal: McGill-Queens University Press, 1993), 92114 (text); 218-31 (notes); public inebriate asylums just before and after Harrison: Jim Baumohl and Sarah W. Tracy, "Building Systems to Manage Inebriates: The Divergent Paths of California and Massachusetts, 1891-1920," Contemporary Drug Problems, 21 (1994), 557-97.

5. Ambulatory treatment in private practice: see the March 16, 1915, remarks of Dr. J.W. McConnell in "Philadelphia West Branch," Pennsylvania Medical Journal, 18 (1914-15), 762. Ambulatory treatment in New York during this period: Musto, note 3, 104-20. In addition to the case texts, see Musto, 131-2; Rufus G. King. "The Narcotics Bureau and the Harrison Act: Jailing the Healers and the Sick," Yale Law Journal, 62 (1952-53), 736-49; Terry and Pellens, note $3,745-806$.

6. Treasury's adoption of exceptions: Terry and Pellens, note 3, 756-7. California: California State Board of Pharmacy (hereafter CSBP), Minutes, Volume 1 (October 22, 1909), 83b, CSA. Pennsylvania: Laws of Pennsylvania, Session of 1917, No. 282, Section 8; Session of 1921, No. 98, Section 8. Pennsylvania data: Harold V. Smith to H.J. Nugent, October 5, 1932, Treasury Department File (hereafter TDF) 0120-9, Folder 2, DEA.

7. Daniel C. Roper (Commissioner of Internal Revenue), "Memorandum for the Secretary," July 15, 1919; Rupert Blue (Surgeon General) to Roper, July 28, 1919, PHS, Box 204.

8. Blue to Roper, note 7. The France Bill and the role of the PHS: Musto, note 3, 144-5, 332-3 (his note 64). The control of venereal disease during World War I: Allan M. Brandt, No Magic Bullet: A Social History of Venereal Disease in the United States Since 1880 (New York: Oxford University Press, 1987), 52-121. 
9. David Courtwright, Herman Joseph, and Don Des Jarlais, Addicts Who Survived: An Oral History of Narcotic Use in America, 1923-1965 (Knoxville: University of Tennessee Press, 1989); quoted passage, p. 1; Musto, note 3, 151-82; Dan Waldorf, Martin Orlick, and Craig Reinarman, Morphine Maintenance: The Shreveport Clinic, 1919-1923 (Washington, DC: Drug Abuse Council, 1974).

10. See Musto, note 3,346-7 (his note 9), for an FBN field supervisor's admission in 1932 that "enforcement in the 1920s was perhaps as bad as physicians and druggists claimed." This note includes the supervisor"s candid language about "black-jacking" and "field men" promoting their careers at the expense of "the professional classes." See also Henry Smith Williams, Drug Addicts Are Human Beings (Washington, DC: Shaw Publishing, 1938). Narcotic agents were not so renegade a lot as Volstead Act enforcers, but for the occasionally critical reminiscences of federal agents who worked from the $1920 \mathrm{~s}$ through the 1930s, see Maurice Helbrant, Narcotic Agent (New York: Vanguard Press, 1941), and William Spillard, Needle in a Haystack (New York: McGraw-Hill, 1945).

11. Purpose of the amendments (in the words of Assistant Treasury Secretary Andrews): "Strengthening the Harrison Narcotic Act," Journal of the American Medical Association, 86 (1926), 1473-4. With the failure of its proposed amendments, which the AMA forcefully opposed in the editorial cited above, Treasury supported a model state law to accomplish many of the same ends, including the abolition of ambulatory treatment and maintenance. The resulting Uniform Narcotic Drug Act was written by a committee of the National Conference of Commissioners on Uniform State Laws between 1927 and 1932. While the conference demurred on specifying methods of treatment, in the spirit of Webb, it did not consider a prescription for maintenance to be "in the course of [a physician's] professional practice." Section 8(a) of the Uniform Act specifically forbade the dispensing or prescription of more than $1 / 2$ grain of morphine to the same patient within $\mathbf{4 8}$ hours. [National Conference of Commissioners on Uniform State Laws, Uniform Narcotic Drug Act (Chicago: Author, 1932).] By October 1938, 40 states had passed the Uniform Act, but California was not among them. On the progress of the act: Harry Anslinger (hereafter HJA), "Address Before the New York Herald Tribune Forum, October 25, 1938," AP, Box 1, File 7.

12. August Vollmer, The Police in Modern Society (Berkeley: University of California Press, 1936), 117.

13. G.A. Horner to James Rolph (mayor of San Francisco), August 9, 1919, RP, Box 49, Folder 591; Anthony Votta to Federal Bureau of Investigation, May 18, 1939 (quoted passages, pp. 8, 10), AP, Box 3, File 1. 
14. See Baumohl and Tracy, note 4 .

15. Los Angeles clinic: Terry and Pellens, note 3,872-6. The patient data: "Report of the Narcotic Committee, 1920," The Bulletin [of the Los Angeles County Medical Association], 51:8 (April 21, 1921), 68 . The clinic charged 10 cents per grain because required to make a profit. Originally this $\$ 2,000$ or so per month was earmarked for institutional treatment of patients, but with recession, inflation, and rapid population growth, the city council appropriated most of it for the general fund.

16. "City's Drug Clinic an Astounding Failure," Los Angeles Examiner, April 22, 1920, section 2, pp. 1, 3; Lee Shippey, "Truth About City Drug Clinic," Los Angeles Times, May 2, 1920 (section 2, pp. 1, 5). The clinic committee's disparagement of "lying influence" (by which it meant the Examiner's): "Report of the Narcotic Committee," note 15, 8. Hutton's letter (Frank S. Hutton to Commissioner of Internal Revenue, May 13, 1921, TDF 0120-1, Folder 2, DEA) refers to the board's opposition to "some of the initial methods" of the clinic. In April this resulted in the replacement of its first medical director and the formulation of 18 rules of procedure by the board and the clinic committee ["Rules for the Narcotic Clinic of Los Angeles," TDF 73221, DEA; CSBP, note 7, Minutes, Volume 5 (April 26, 1920), 116a-b]. Powers and Carter: Terry and Pellens, note $3,875-6$.

17. Lee Ettelson, "U.S. Banishes Dope Clinics," Los Angeles Examiner, August 13, 1920, section 1, pp. 1, 4.

18. H.L. Kirby to Hugh S. Cumming, October 26, 1923, PHS, Box 206. The bureau's director, Kirby came from the Committee on Drug Addictions in New York, of which Dr. Charles Terry (1878-1945) was executive. Terry was the father of organized morphine maintenance, having established the first such clinic in Jacksonville, Florida, in 1912.

19. The membership of this committee overlapped substantially with the bureau's medical division. And just as the bureau arose in part from the dissatisfaction of some Board of Pharmacy members with Treasury's revised clinic policy, the LACMA committee was organized by the board's Los Angeles attorney to "examine certain addicts who claimed for one reason or another that they required narcotics." If the committee found good cause, it would provide treatment "in accordance with the law." The Pharmacy Board's dissatisfaction with Treasury's clinic policy: Hutton to Commissioner, note 16, and Board of Councillors, Minutes, March 28, 1921, LACMA. On the establishment of the LACMA's review and treatment function, about which its councillors became confused in later years: CSBP, Minutes, note 6 , Volume 8 (January 10,1925 ), 148. 
20. Board of Councillors, Minutes, August 13, 1934, LACMA. The clinic's director at this time was Dr. Joseph J. O'Brien (1881-1958).

21. H.S. Williams, note 10,37 . Jost would have underdosed most addicts, but its critics never mentioned that it provided too little rather than too much. See AB 1433 (1931), Original Bill File, CSA.

22. Spadra's enabling legislation: Statutes of California, Forty-Seventh Session (1927), Chapter 89; Statutes of California, Forty-Eighth Session (1929), Chapter 406. Joyce in New York: Thomas F. Joyce, "Denarcotizing the Addict," Monthly Bulletin of the Department of Health (New York City), June 1921, 132-6.

23. Baumohl and Tracy, note 4 (the struggle over commitments); Sanborn Young, "A Relentless War," State Government, ca. 1933, AP Box 6, File 1 (Governor Clement Young's incremental approach); "Report of Medical Superintendent of State Narcotic Hospital," in Appendix to the Journals of the Senate and Assembly of the Forty-Ninth Session of the Legislature of the State of California (Sacramento: State Printer, 1931), Volume 1, 176 (changes in security); State Narcotic Committee, "The Trend of Drug Addiction in California," in Appendix to the Journals of the Senate and Assembly, as above, Volume 5, 29 (Joyce on desirable patients); William $\mathbf{H}$. Jordan, "Larger State Dope Hospital Plan Adopted," San Francisco Examiner, January 16, 1931, AP, Box 6, File 5; "Assembly Passes Bills to Strengthen State Narcotic Act," San Francisco Examiner, April 9, 1931, 20; "Spadra Measure Signed by Rolph," San Francisco Examiner, April 25, 1931, 11 (superintendent's discretion).

24. "Police Will Push Campaign on Dope," San Francisco Examiner, February 27, 1931, 2. Although detailed San Francisco arrest data for the 1930 s are elusive, there were 106 "vag-addict" arrests there between June 9 and October 10,1930, and 658 during calendar year 1935 [State Narcotic Committee, note 23, 34; State of California, Senate Interim Narcotic Committee, Report on Drug Addiction in California (Sacramento: State Printer, 1936), 67]. Along with his maintenance bill, Jost introduced unsuccessful legislation in 1931 to repeal the state's "vag-addict" law, passed in 1929 and sponsored by Young. The vagrancy law had been used to prosecute addicts since 1875 , but Young broadened its scope. See Jim Baumohl, "The 'Dope Fiend's Paradise' Revisited: Notes from Research in Progress on Drug Law Enforcement in San Francisco, 1875-1915," The Surveyor, 24 (June 1992), 3-12.

25. Votta to FBI, note 13, 7-8. Other evidence supports Votta's account of the rapid escalation of morphine's street price: see "2 Admit Guilt as Dope Chiefs," San Francisco Examiner, April 3, 1931, 6. Federal agents in California seized over four times the weight of drugs in the last five months of 1930 than during the whole year preceding July 1, 1930. Most seizures occurred in San Francisco, where the FBN 
was going after "the larger dealers" rather than "chasing vagrant addicts." (Smith to HJA, December 29, 1930, AP, Box 3, File 10.)

26. Dismissal of cases: Senate Narcotic Committee, note 24, 35; AB 1433, note 21 , Sections 3 and 4

27. Smith to HJA, March 7, 1931, TDF 0120-1, Folder 2, DEA; Joyce's opinion: William H. Jordan, "Narcotic Foes Unite Against Jost's Bills," San Francisco Examiner, February 20, 1931, 4.

28. Herbert L. Phillips, " 'Dope Clinic' Bill Killed," San Francisco Examiner, March 18, 1931, 4; Annie Laurie, "Legislators, Do We Want 'Dope Clinics' to Return," San Francisco Examiner, March 12, 1931, 13. Federal agents had long promoted the magnet theory: see J.S. Considine to Federal Prohibition Commissioner, August 4, 1920 , TDF 73221, DEA, and C.D. Writesman to L.G. Nutt, May 1, 1924, TDF 0120-9, Folder 1, DEA

29. William H. Jordan, "State to Gain New Power Over Addicts," San Francisco Examiner, March 19, 1931, 4.

30. The "drive" against "physicians dispensing . . . freely to addicts" was planned on Anslinger's December 1933 visit to Los Angeles ("California," ca. December 1934, AP, Box 8, File 8). Its seeds were sown a month earlier, however, when the Hearst papers began a related campaign to help Anslinger and William Walker, director of California's narcotics enforcement division, defend their budgets against Depression cost-cutting. See "Unscrupulous Doctors Complicate Task of Handicapped Dope Squads," Los Angeles Examiner, November 5, 1933; Walter Naughton, "Dope Selling Doctors Increase as U.S. Cuts Enforcement Fund," San Francisco Examiner, November 6, 1933, AP, Box 6, File 1.

31. "5 Doctors Seized on Dope Charges; City Clinic Probed," Los Angeles Examiner, April 25, 1934, sec. 2, p. 1; "Sixth Doctor Surrenders; Denies U.S. Dope Charges," Los Angeles Examiner, April 26, 1934, sec. 1, p. 5. The pharmacists were quickly released with warnings. LACMA volunteers: "Council Votes Dope Funds," Los Angeles Examiner, April 14, 1934, sec. 1, p. 7.

32. On Parrish: membership file, LACMA. Conditions: "Police Seek Supervision of Dope Addicts," Los Angeles Examiner, May 1, 1934, sec. 1, p. 5. These conditions were based on the FBN's interpretation of Treasury Decision 2809 of March 20, 1919, which spelled out exceptions to anti-maintenance policy. This decision also warned: "Physicians will be held accountable if through carelessness or lack of sufficient personal attention the patient secures more narcotic drugs than are necessary for medical treatment, and devotes part of his supply to satisfy addiction." Since maintenance and medical 
treatment often were inseparable, this regulation was a license for harassment.

33. The May 11 meeting and Anthony's subsequent experience: United States v. Anthony et al. (15 F. Supp. 553) and "Two Dope Suspects Face Trial Oct. 16," Los Angeles Examiner, October 2, 1936, sec. 2, p. 16; Williams and Steele: clipping from the Los Angeles Times, August 2, 1934; E.H. Williams, membership file, LACMA; "Cal1698," Department of Justice, Mail and Files, File No. 12-12, Sub. 55, National Archives, Washington, DC.

34. Williams to Vollmer, June 6, August 10, and August 23, 1934, VP, Box 33. For a partisan but penetrating view of "The Los Angeles Reign of Terror," see Henry Smith Williams, Drugs Against Men (New York: Robert M. McBride \& Company, 1935), 167-81.

35. Marking Williams: Considine to federal prohibition commissioner, note 28; the LACMA discussion can be followed in Board of Councillors, Minutes, May 7, 1934; July 2, 1934; August 13, 1934; January 7, 1935; February 4, 1935; December 2, 1935; January 6, 1936; February 3,1936, LACMA. At the beginning of the Williams-Cary trial, discussed below, Dr. Clifford Wright of the Narcotic Committee did make a widely publicized speech in support of the doctors to the Los Angeles County Federation of Women's Clubs (Jean Loughborough, "Better Narcotic Control Urged at Club Meeting," Los Angeles Examiner, October 12, 1934, sec. 2, p. 3).

36. For the FBN's allegations, see HJA, "Memorandum for Mr. Gaston," June 28, 1934, AP, Box 3, File 6.

37. Williams did not become aware of the charges in Anslinger's memo until after his trial with Cary. They were revealed during a subsequent misconduct proceeding against the federal prosecutor. For quotations from the transcript, further discussion of the FBN's claims, and a detailed refutation, see Williams to Harry $\mathrm{H}$. Wilson, March 26, 1935, VP, Box 33.

38. Williams, Opiate Addiction, note 4, 20-1; U.S. v. Anthony et al., note 33. Even the FBN conceded the grave illnesses of most patients, but disputed the appropriateness of maintenance and the size of the morphine doses.

39. Editorial, Hollywood Citizen-News, May 21, 1934, VP, Box 33. Biographical information: E.H. Williams, membership file, LACMA; "E.H. Williams, Noted Alienist, Succumbs at 75," Los Angeles Times, June 25, 1944, sec. 2, p. 7 . Williams is best known to drug historians as a contributor to the myth of the "cocainized Southern negro" (Musto, note 3, 282-4, his notes 15, 20). 
40. HJA, "Memorandum for Mr. Gaston," note 36; "California," note 30. An article that appeared in the Washington Herald (a Hearst paper) in December 1934 had Anslinger assailing the International White Cross's "notorious" clinic proposal and naming Williams as the organization's founder ("Medical Group Fighting 'Dope' Curb, Is Charge," Washington Herald, December 7, 1934, AP, Box 5, File 15). But neither of the Williams brothers was a "joiner" or an optimist about "organized reform" (H.S. Williams to Alfred R. Lindesmith, November 9 and November 10, 1939, LP; E.H. Williams to Vollmer, September 30, 1934, VP, Box 33).

41. Cary's sentence: "Dope Case!" Los Angeles Examiner, January 10, 1935, sec. 2, p. 8; his trial: "Trial of 2 Doctors Charged with Dope Conspiracy Starts," Los Angeles Examiner, October 10, 1934, sec. 2, p. 1; "Legal Right to Prescribe Narcotics, Doctors' Defense," Los Angeles Examiner, October 11, 1934, sec. 1, p. 16; "Lawyer in Federal Dope Trial Cited for Contempt," Los Angeles Examiner, October 13,1934 , sec. 1, p. 3; H.S. Williams, note 10, 187-93. Denial of appeal: Cary et al. v. United States ( $86 F .2 d 461)$. On the outcome for E.H. Williams, see his letter to Vollmer, May 28, 1939, VP, Box 33. Dropped charges: Department of Justice, note 33. The agent-incharge (Chris Hanson): Alfred Lindesmith, The Addict and the Law (Bloomington, IN: Indiana University Press, 1965), 15-6.

42. U.S. v. Anthony et al., note 33.

43. H.S. Williams, note 10, 66-67 (summary of committed cases); 68-70 (deceased patients); 109-10 (former patient's letter). On informer Madge Surber, promoted to "secret dope sleuth" by the Examiner upon her demise: "Dope Sleuth Slugged. Dies," Los Angeles Examiner, October 1, 1934, sec. 1, p. 3. Most of the data Williams presented were gathered by Everett G. Hoffman of the Seattle White Cross during the summer of 1937. By examining Los Angeles court records, Hoffman found that of 65 patients tracked over three years of clinic attendance, none had been in court during that time. Prior to clinic enrollment, this group had 311 arrests over an unspecified period of time. In the three years after the clinic's closure, 41 of the former patients accounted for 63 arrests (Hoffman to Lindesmith, January 24,1938 , LP).

44. Young to HJA, March 24, 1934, AP, Box 3, File 6.

45. There is no secondary literature on the White Cross. My understanding of its history comes from promotional material and Alfred Lindesmith's correspondence with Everett G. Hoffman.

46. "Anti-Narcotic League's Fund Campaign Hit," Los Angeles Examiner, July 3,1934 , sec. 1, p. 8 . 
47. "Inherently crooked": "White Cross Wins Delay," Los Angeles Times, June 13, 1934, sec. 2, p. 3; "Anti-Narcotic League Bitterly Denounced at Social Service Hearing," Los Angeles Examiner, July 4, 1934, sec. 1. pp. 3, 6; "Drive Fund Losses Told," Los Angeles Times, July 3, 1934, sec. 2, pp. 1-2; "White Cross Plea Denied," Los Angeles Times, July 11, 1934, sec. 2, pp. 1, 5.

48. "Anti-Narcotic League Bitterly Denounced," note 47; "White Cross Inquiry Ends," Los Angeles Times, July 4, 1934, sec. 2, pp. 1-2. Although Young did not call West a communist-not publicly, at least-his vilifying rhetoric was borrowed from the contemporaneous anti-communist crusade in California, of which he was a leader, supported in part by anti-narcotic regulars like the WCTU. See, for example, "Red Menace Rouses City," Los Angeles Times, May 17, 1934, sec. 2, p. 8.

49. "The White Cross Decision," editorial, Los Angeles Times, July 12, 1934, sec. 2, p. 4. "Criminal desire": "Anti-Narcotic League Bitterly Denounced," note 47; "White Cross in New Row," Los Angeles Times, June 20, 1934, sec. 2, pp. 1-2.

50. "Anti-Dope Body Loses Support," Los Angeles Times, June 11, 1934 , sec. 1, p. 3.

51. "Dope Addicts: Olson Studies New Aid Plan," San Francisco News, December 10, 1938, TDF 0120-1, Folder 2, DEA; Walker to Washington State Senator Paul Thomas, December 29, 1938, LP.

52. HJA to Young, July 6, 1933; HJA to Walker, July 6, 1933; Walker to HJA, October 30, 1933, AP, Box 3, File 7; Bernard Taper, "A 'Prohi' Remembers Volstead Era," San Francisco Chronicle, August 4, 1952, p. 17: "William G. Walker," San Francisco Chronicle, February 24, 1956, p. 25.

53. The division's turmoil and near abolition: "Narcotics Charge Examples Given," unidentified clipping, ca. November 14, 1932, AP, Box 6. File 4; "Senator Young Dope Charges Hit by Rolph," San Francisco Examiner, November 17, 1932, 3; William H. Jordan, "Government Acts to Prevent California Wrecking Laws Against Dope," San Francisco Examiner, February 16, 1933, AP, Box 6, File 7; "Levey Opposes Abolition of Dope Bureau," San Francisco Examiner, February 18, 1933, AP, Box 6, File 3. Walker's "coloring": "Faking the News," editorial, San Francisco News, November 11, 1933; "Walker Admits Dope Charges Propaganda," San Francisco News, November 11, 1933, AP, Box 6, File 1. The colored story: [Wooster Taylor], "Dope Ring Linked to Traffic in Girls," San Francisco Examiner, November 3, 1933, AP, as above. Walker on marijuana ("horrible in its effects") in late 1933: Wooster Taylor, "Dope Officials Helpless to Curb Marihuana Use," San Francisco Examiner, November 7, 1933, AP, Box 6, File 1. He expressed simi- 
lar views ("serious menace") in a February 18, 1935, radio address, quoted at length in Michelsen to Olson, December 17, 1938. TDF 0120-1, Folder 2, DEA. Differences: Young to HJA, December 23, 1938, TDF 0120-1, Folder 2, DEA.

54. "Two years more": William H. Jordan, "California Hailed as Dope Fight Leader," San Francisco Examiner, March 2, 1931, 8. Division budget cuts and effects: "Dope Bureau Urges Support," Los Angeles Examiner, October 5, 1934, sec. 1, p. 11. County obligations: Spadra's enabling legislation (note 22). Implications: Paul E. Madden (chief, division of narcotic enforcement) to Randal F. Dickey (California Assemblyman), March 13, 1941, TDF 0120-8, DEA. Director of Institutions (Dr. J.M. Toner): "State's Dope Patient List Shows Decline," San Francisco Examiner, November 20, 1933, AP, Box 6, File 1. Joyce's assistant (Dr. Robert Wyers): Marjorie Driscoll, "Two Congressmen Visit Spadra; Rap Dope Budget Cut," Los Angeles Examiner, November 13, 1933, AP, as above. Spadra's census in October 1937: Hoffman to Lindesmith, January 8, 1938, LP.

55. Winning Rolph: R.E. Hall (acting district supervisor) to HJA, August 26, 1932; HJA to Rolph, September 12, 1932; Toner to HJA, September 23, 1932, TDF 0120-8, DEA. Constituencies: "Save State Narcotic Hospital at Spadra," editorial, Los Angeles Examiner, February 20, 1933, AP, Box 6, File 3; Bonfils to HJA, February 20, 1933, AP, Box 3, File 7; Joyce to HJA, February 24, 1934; Laura Seeley-Thomson (Federation of Women's Clubs) to HJA, February 24, 1934, TDF 0120-8, DEA. Rolph's health: Young to HJA, March 24, 1934, AP, Box 3, File 6. Rolph's administration: H. Brett Melendy and Benjamin F. Gilbert, The Governors of California (Georgetown, CA: Talisman Press, 1965), 363-80.

56. Walker to HJA, January 23, 1934, TDF 0120-8, DEA.

57. Smith to HJA, January 31, 1934; HJA to Sanford Bates (director of the Federal Bureau of Prisons), February 2, 1934; Bates to HJA, February 6, 1934; HJA to Walker, Young, and Smith, February 7, 1934, TDF 0120-8, DEA.

58. John Knox to Young, January 26, 1934; Young to HJA, February 8 and March 23, 1934, TDF 0120-8, DEA.

59. Young to HJA, October 1, 1934, TDF 0120-8, DEA; Thomas F. Joyce, "What Shall We Do with California's Incurable Narcotic Addicts?" in Senate Interim Narcotic Committee, note 24, 49-51. After 1932 Young pursued a secondary strategy of adding to Spadra a facility for women, who as of 1931 went to Norwalk State Hospital because sex segregation at Spadra proved difficult. (At first Young favored sending female addicts to the women's prison due to open in Tehachapi in 1932, but that put him in conflict with the Hearst papers and women's groups.) By the end of 1934, with public-drunk- 
enness arrests and state hospital admissions for alcoholism rising with the Depression, Repeal, and population growth. Joyce wanted to admit alcoholics to Spadra. See Otheman Stevens, "Need of Dope Hospital to Cure Women Stressed," San Francisco Examiner, April 2, 1931, 19; "Hospital Care Needed for Women Victims of Dope," editorial, San Francisco Examiner, April 3, 1931, 36; Otheman Stevens, "Women Dope Victims Face Prison Brand," San Francisco Examiner, April 4, 1931, 15; "Same Care Should Be Given Dope Victims of Both Sexes," editorial, San Francisco Examiner, April 28, 1931, 34; William H. Jordan, "Rescue Addicts!" Los Angeles Examiner, December 21, 1934, sec. 2, p. 1.

60. Parrish, note 1 .

61. Examples of press criticism: "Narcotics Free Clinic Plan Rapped," San Francisco Chronicle, December 9, 1938; "Experts Denounce Walker Dope Plan," San Francisco Examiner, December 15, 1938; "Walker Ouster Study Revealed," San Francisco Examiner, December 16, 1938; "Neglect Laid to Walker," San Francisco CallBulletin, December 20, 1938; "Walker's Dope Plan Assailed by Anslinger," San Francisco Examiner, December 20, 1938; "Walker's Plan Denounced by Senator Young," undated, unidentified clipping, TDF 0120-1, Folder 2, DEA.

In "Federal Narcotics Bureau Refuses Job to Walker," a San Francisco Examiner piece of December 14 (TDF 0120-1, as above), the reporter claimed that "leaders in the fight to curb drug addiction" pointed out that "Walker's policies . . undoubtedly were well known to Commissioner Anslinger long before the State official made his declaration at the budget hearing. . . The rejection of Walker's plea for a federal post, it was indicated, was based on careful study of his administrative methods and ideas over a period of years." This was sheer fabrication, phrased so that the words were not put in Anslinger's mouth. In a December 7 telegram to Michelsen, Anslinger did say that Walker had "applied for position this bureau but could not find it possible to place him." Note that he did not say that the inquiry was recent or that Walker was objectionable. Moreover, in letters to Michelsen and Young, Anslinger implied that he was completely unaware of Walker's views on clinics. (HJA to Michelsen, December 7 and 28, 1938; HJA to Young, December 28, 1938, TDF 0120-1, as above). Gaston's handwritten, undated note to Anslinger is in the same file.

Michelsen's remark about Walker catering to "perverted tastes" was in a San Francisco political newsletter that he sent to Anslinger, who liked the phrase and repeated it in his answering letter (HJA to Michelsen, February 9, 1939, TDF 0120-1, Folder 3, DEA). Petitions from chapters of the California Federation of Women's Clubs are also in this file. Anslinger forwarded one of these to Governor Olson, probably as an excuse to register his displeasure with Walker 
by including his response to the Federation of Women's Clubs president. In this Anslinger remarked that "we have found the clinic-system far more dangerous than narcotic peddlers in causing a tremendous increase in drug addiction." (HJA to Mrs. I.H. Teilman, February 7, 1939, TDF 0120-1, Folder 3, DEA.) There was no evidence for such a conclusion.

62. HJA to Young, February 13, 1939, TDF 0120-1, Folder 3, DEA. Olson's views of alcohol control: "Olson Asks State [to] Take Over Liquor," Los Angeles Examiner, January 18, 1935, sec. 1, p. 8.

63. Walker's career after 1939: Taper, note 52. Doom: Young to HJA, December 23, 1938, TDF 0120-1, Folder 2, DEA. It seems that only the intervention of Elizabeth Bass, a doyenne of the Democratic Party and a Roosevelt appointee to the FBN (she was Anslinger's top political operative), persuaded Olson to keep Spadra open during the early part of his administration. (Elizabeth Bass to Franklin Delano Roosevelt, June 18, 1939, FDR, OF, Box 919, Eliz. Bass.) Rosanoff's views: Michelsen, "An Open Letter to Dr. Aaron J. Rosanoff," TDF 0120-8, DEA; Madden to Dickey, note 54. Anslinger told Rosanoff in February 1940 that California could not use federal courts to commit addicts to Lexington, Fort Worth, or Alderson (West Virginia, for women) without federal legislation to permit it. "Furthermore," Anslinger wrote, such a law would encourage the states "to shirk their duty." (HJA to Rosanoff, ca. February 1940, cited in Madden to Dickey.)

64. "Police Aide Urges Free Narcotics for Dope Addicts," Fresno Bee, April 17, 1940, TDF 0120-1, Folder 3, DEA.

65. Michelsen to Mrs. Maddux, April 22, 1940; Michelsen to HJA, May 13, 1940; Joseph Manning to HJA, April 30, 1940, all TDF 0120-1, Folder 3, DEA.

66. J.A. Greening (Berkeley chief of police) to HJA, October 7, 1940; Warren to Smith, October 1, 1940; Warren to Barbeau, October 1, 1940, all TDF 0120-1, Folder 3, DEA.

67. Barbeau to Warren, October 8, 1940; Warren to Smith, October 14, 1940, both TDF 0120-1, Folder 3, DEA.

68. No meeting had occurred by mid-December, and Smith, having called a significant chip, was by then frustrated with Anslinger's failure to thank Warren personally for the intervention. Smith to HJA, October 5, 1940; Smith to Warren, December 19, 1940, both TDF 0120-1, Folder 3, DEA.

69. Alfred Lindesmith, "Dope Fiend Mythology," Journal of Criminal Law and Criminology, 31 (1940), 199-208 (cited passage, 208). 
70. HJA to Gaston, September 17, 1940; Gaston to HJA. ca. September 17, 1940, both TDF 0120-1. Folder 3, DEA.

71. Twain Michelsen, "Lindesmith's Mythology," Journal of Criminal Law and Criminology, 31 (1940), 375-400 (cited passage, 400). Although the Williams brothers' names appeared on WNRF literature, Henry denied to Lindesmith that they were in any way involved and wrote that Edward had explicitly requested that his name be removed (H.S. Williams to Lindesmith, note 40 ).

72. Lindesmith claimed that the FBN was behind Michelsen's attack, and there can be no doubt of it. On his harassment by the FBN, see Lindesmith, note $41,254-7$.

73. New State Ice Co. v. Liebmann (265 U.S. 262).

74. "Former Club Woman Faces Dope Trial," San Francisco Examiner, May 6, 1931, 19; "Former Club Leader Given Dope Sentence," San Francisco Examiner, May 10, 1931, sec. 1, p. 16.

75. "Former Club Leader," note 74.

76. Historian David Courtwright [Dark Paradise: Opiate Addiction in America before 1940 (Cambridge: Harvard University Press, 1982)] argued that as conservative medical practices reduced iatrogenic addiction, the locus of opiate addiction moved from middle-class to lower-class and sporting circles in the decades before Harrison. Historical epidemiology is something of an empirical rabbit hole, but his point seems accurate. Even so, there were many addicts not caught up in a wider pursuit of vice, and this was the point hammered on by the White Cross.

77. Votta to FBI, note 13.

78. Kolb to HJA, June 29, 1939, AP, Box 3, File 1.

79. Kolb to HJA, note 78. For an explication of this dilemma in disability determination, see Deborah A. Stone, The Disabled State (Philadelphia: Temple University Press, 1984).

80. For the biographical origins of Sinith's "natural hatred for narcotic drugs in any form and for any person who trafficked in them," see Smith to HJA, September 5, 1940, AP, Box 2, File 21.

81. The FBN's disregard for Linder went well beyond typical "agency nonacquiescence." Usually, this is a formally declared or informal practice whereby a federal agency chooses not to change its regulations on the basis of an adverse circuit court decision. The most common form is called "intercircuit nonacquiescence," and it occurs when an agency chooses not to honor the ruling of a circuit other than the one that will review whatever case is at hand. "Intracircuit 
nonacquiescence" is more rare and is confrontational in that the agency refuses to abide by the decision of a circuit court even within that court's jurisdiction. The Internal Revenue Service (a Treasury Department agency) began to practice such tactics at about the time of Linder. See Samuel Estreicher and Richard L. Revesz, "Nonacquiescence by Federal Administrative Agencies," The Yale Law Journal, 98 (1989), 679-772. "Lusty applications": King, note 5, 748.

Dr. David Lewis (personal communication) notes that Anslinger's FBN regarded Linder as obiter dictum and thus beside the point of legal precedent and substantive policy. Even so, the Supreme Court does not seem to have regarded the decision's provisions for goodfaith practice as mere legal aside. The White Cross's Everett Hoffman claimed that Justice McReynolds (Linder's author) told him in 1926 that "the recent Linder decision would protect the doctors henceforth." Hoffman was skeptical: "I told him that he did not know the Narcotic Bureau," he recalled (Hoffman to Lindesmith, January 8, 1938, LP). In any event, the failed Smoot Amendments to Harrison in 1926 and the subsequent development of a uniform state narcotic law (see note 11) clearly indicate that Treasury officials took Linder's practical threat to Webb quite seriously. The decision was thus ignored at every opportunity.

82. Anslinger's views on treatment: "The Narcotic Problem," speech to the Attorney General's Conference on Crime, December 13, 1934 (AP, Box 1, File 7). Anslinger thought highly of German eugenic colonization and of an Alaskan version proposed by a Washington state hospital doctor opposed to the program of the Seattle White Cross. Harry Smith was similarly enthusiastic, but Kolb called the idea "absurd." H.L. Sharman, Anslinger's Canadian counterpart, offered a more polite dissent: Addiction was in decline, he wrote from Ottawa, even without extreme policies like "narcotic bar-rooms" (maintenance clinics) or "permanent leper islands." See HJA to Dr. J.W. Doughty, October 14, 1936; HJA to His Excellency the Governor of Washington, January 10, 1941; Smith to HJA, January 30, 1941; Kolb to HJA, February 5, 1941; Sharman to HJA, February 3, 1941, all TDF 0120-8, DEA. For the proposal, see J.W. Doughty, "State Farm Colony," in Third Annual Report of the Department of Finance, Budget and Business (Olympia: State Printer, 1940), 160-1.

83. Joint Committee of the American Bar Association and the American Medical Association on Narcotic Drugs, Drug Addiction: Crime or Disease? (Bloomington, IN: Indiana University Press, 1961; this volume includes both the interim and final reports of the joint committee); Advisory Committee to the Federal Bureau of Narcotics, Comments on Narcotic Drugs/.J Interim Report of the Joint Committee of the American Bar Association and the American Medical Association on Narcotic Drugs (Washington, DC: U.S. Treasury 
Department. Bureau of Narcotics, 1958). Michelsen's comments: 72-104; quoted passages: $86,95$.

84. Depression-era tax mechanisms: Marvel M. Stockwell, Studies in California State Taxation, 1910-1935 (Berkeley: University of California Press, 1939); federal, state, and local financial relationships Winston W. Crouch, State Aid to Local Government in California (Berkeley: University of California Press, 1939); hostile treatment of impoverished migrants: Walter J. Stein, California and the Dust Bowl Migration (Westport, CT: Greenwood Press, 1973); Carey McWilliams, Southern California: An Island on the Land (Santa Barbara: Peregrine Smith, 1973; originally published 1946); Gregory R. Woirol, In the Floating Army: F.C. Mills on ltinerant Life in California, 1914 (Urbana: University of Illinois Press, 1992). 


\section{Notes on contributors}

LESTER GRINSPOON is a professor Emeritus of psychiatry (Harvard Medical School) (35 Skyline Drive, Wellesley, MA 02482; Igrinspmd@aol.com). Founding editor of both the Annual Review of Psychiatry and the Harvard Mental Health Letter, Dr. Grinspoon's 12 books include Marihuana Reconsidered (first published 1971) and (with James Bakalar) Marihuana, the Forbidden Medicine (last revised 1997).

JIM BAUMOHL is on the faculty of the Graduate School of Social Work and Social Research, Bryn Mawr College, 300 Airdale Rd., Bryn Mawr, PA 19010. He edited Homelessness in America (1996) and writes frequently about social welfare policy and the history of alcohol and drug treatment.

AMANDA NOBLE, DORIE KLEIN, ELAINE ZAHND, and SUE HOLTBY are research scientists at the Public Health Institute (2001 Addison St., 2nd Floor, Berkeley, CA 94704-1103; alnoble@ucdavis.edu). Amanda Noble is also a research associate in the Department of Sociology at the University of California, Davis. She has a longstanding interest in women's drug use and is currently working on aspects of U.S. welfare reform that affect women with arrests or other problems from drug use. Criminologist Dorie Klein has worked on issues concerning women in treatment and justice systems and on alcohol and drug policy. Elaine Zahnd is a sociologist interested in policy-related research on women's behavioral health, substance abuse, family violence, and welfare. Sue Holtby is in public health, with research interests in family planning, substance abuse, and access to services for poor women.

GEORGE S. YACOUBIAN, JR. is a research associate at the Center for Substance Abuse Research (CESAR, 4321 Hartwick Rd., Suite 501, College Park, MD 20740; yacoubiang@cesar.umd.edu) and a doctoral student in the Department of Criminology and Criminal Justice at the University of Maryland.

JUKKA TÖRRÖNEN is a contract researcher at the Finnish Foundation for Alcohol Studies (STAKES, P.O. Box 220, 00531 Helsinki, Finland; jukka.torronen@stakes.fi). Currently working on a project 